Acta Poetica 32•1

ENERO-JUNIO

$2011(19-87)$

\title{
Tiempo y poesía
}

\author{
Antonio Alatorre
}

Este artículo-antología que Antonio Alatorre nos entregó varios meses antes de morir reúne una serie de sonetos que tienen como tema el paso del Tiempo. Comienza con unos versos de Ovidio y sigue con las traducciones $\mathrm{y}$ adaptaciones hechas por algunos poetas renacentistas italianos; pero la mayoría de estos sonetos se deben a poetas ibéricos (españoles y portugueses, y alguno también catalán) de los siglos XVI y XVII. En la selección se da preferencia a los sonetos "de artificio": en ella encontramos sonetos en "eco", sonetos continuos, sonetos construidos a base de anáforas, etc. A manera de coda, Alatorre añade uno del siglo XVIII y otros de algunos poetas mexicanos del xx que siguen la misma línea temática y formal comenzada con Ovidio. El gusto con que elige estas piezas, y el cuidado con que va engarzándolas, ilustran a la perfección esa mezcla de amenidad y rigor filológico que caracterizan el estilo de Alatorre. No falta aquí tampoco la elegante colocación de algunos puntos sobre algunas íes.

Palabras clave: Soneto, Tiempo, Siglos de Oro, poesía renacentista, poetas ibéricos, siglos XVI-XVII, soneto continuo, soneto en "eco".

This "article-anthology" given to us by Antonio Alatorre several months before his death consists of a series of sonnets about the passing of time. It begins with a passage by Ovid, which is followed by some translations and adaptations by Italian Renaissance poets; however, the majority of the sonnets gathered here were written by Iberian poets - Spanish, Portuguese and even a couple from Catalonia - in the 16th and 17th centuries. In choosing these poems, Alatorre privileges pieces that are formally quite sophisticated: thus we find echo sonnets, sonnets written as continuous poems, sonnets structured around anaphora and so on. As a coda to the collection, Alatorre adds a few sonnets from the last couple of centuries that follow the same 
thematic and formal pattern as the Ovid sonnet that opened the anthology - one by an 18th century Spanish poet and a few by 20 th century Mexican poets. The obvious delight that the author takes in choosing these poems and the care he takes in putting them together illustrate brilliantly that mix of sparkling creativity and philological scholarship that is so characteristic of Alatorre's style.

Keywords: Sonnet, Time, Golden Age, Renaissance poetry, Iberian poets, 16th-17th centuries.

Fecha de recepción: 12 de mayo de 2010 
Antonio Alatorre

El Colegio Nacional y El Colegio de México

\section{Tiempo y poesía ${ }^{1}$}

Las páginas que siguen no tienen más objeto que ofrecer a los lectores un ramillete de sonetos que se refieren al Tiempo, tema "eterno" de la literatura - y en especial de la poesía - de todas las naciones, al lado del Amor con sus gozos y sus penas, la Naturaleza (cielo y tierra), los Dioses y los Héroes, la Vida y la Muerte, el Destino, lo Hermoso, lo Aterrador, y también el lado alegre de las cosas...

Los autores de estos sonetos son poetas o versificadores ibéricos (o sea españoles y portugueses) de los siglos XVI y XVII que meditan sobre el Tiempo — su poder, su velocidad, su inexorabilidad, su soberana indiferencia, etc.- - o que lo increpan, o le piden un favor...

La selección ha sido muy difícil. He preferido aquellos sonetos en que el "asunto" va trabado con una "forma" artificiosa y bien trabajada. En otras palabras, predominarán en este ramillete los "sonetos de artificio".

\footnotetext{
${ }^{1}$ Agradezco de todo corazón la ayuda de Antonio Carreira.
} 
Comienzo con unos sonetos cuya hechura se remonta, en última instancia, al muy artificioso y elegante Ovidio. En su Ars amatoria, obra maestra de frivolidad y cinismo (manual del seductor, método para triunfar de la resistencia de las mujeres), Ovidio se muestra como hombre experimentado que da consejos útiles a los principiantes. En un pasaje les dice que no se desanimen si la mujer apetecida parece inconquistable: ya verán cómo acabará por rendirse. Con el tiempo los novillos bravíos toleran el yugo; con el tiempo los potros salvajes se someten al freno; con el tiempo se desgasta un anillo de hierro; con el tiempo se embota la reja del arado. ¿Hay cosa más dura que un peñasco, cosa más blanda que el agua? Pues el agua acaba por hacer un surco en el peñasco:

Tempore difficiles veniunt ad aratra iuvenci;

Tempore lenta pati frena docentur equi;

Ferreus adsiduo consumitur anulus usu;

Interit adsidua vomer aduncus humo.

Quid magis est saxo durum, quid mollius unda?

Dura tamen molli saxa cavantur aqua... ${ }^{2}$

Años después, desterrado por Augusto a orillas del Mar Negro, lugar inhóspito, todavía bárbaro, se acuerda Ovidio de lo que ha dicho sobre el poder del tiempo, y lo repite, pero ahora con intención muy diversa:

Tempore ruricolae patiens fit taurus aratri, Praebet et incurvo colla premenda iugo;

Tempore paret equus lentis animosus habenis, Et placido duros accipit ore lupos;

${ }^{2}$ Ovidio, Ars amatoria, I, vv. 471-478. 
Tempore Poenorum compescitur ira leonum,

Nec feritas animo, quae fuit ante, manet;

Quaeque sui monitis obtemperat Inda magistri

Belua, servitium tempore victa subit...

Sí, con el tiempo se amansan los toros y caballos, con el tiempo se doman leones y elefantes... Y prosigue: el tiempo hincha las uvas, hace germinar las semillas, desgasta pedernales y diamantes, aplaca la más furibunda cólera, alivia los dolores... Todo lo puede el tiempo mientras calladamente va corriendo, salvo atenuar los dolores del pobre desterrado:

\section{Cuncta potest igitur tacito pede lapsa vetustas}

Praeterquam curas attenuare meas. ${ }^{3}$

Los poetas italianos del Renacimiento hicieron "renacer" no solo las reglas de la antigüedad clásica para hacer poesía, sino también muchos de los temas y de los recursos que los antiguos usaron. He aquí cómo uno de ellos, Girolamo Angeriano, imita la anáfora ovidiana (Tempore esto, Tempore lo otro...); él prescinde de toros, caballos y leones, y piensa más bien en la acción del tiempo sobre las obras hechas por el hombre (edificios e instituciones) y sobre las obras de la Naturaleza, para terminar diciendo que el tiempo ( $¡$ ay!) es incapaz de borrar el amor que siempre le tuvo a su difunta Lidia:

Tempore tecta ruunt, praetoria, tempore vires, Tempore quaesitae debilitantur opes [...];

Tempore montani lapides, et tempore virtus

Occidit, et regum tempore defit honor [...];

Tempore fit caelum variabile; tempore Phoebus

Luce caret, scriptum tempore marmor abit;

${ }^{3}$ Ovidio, Tristia, IV, elegía 6, vv. 1-18. 
Tempore durities decedit, tempore livor.

At meus, heu! nullo tempore cessat amor. ${ }^{4}$

Otro tanto (pero en lingua volgare) hace Calmeta, contemporáneo de Angeriano:

Co 'l tempo passan gli anni, e mesi, e l'ore;

co 'l tempo le ricchezze, imperio e regno;

co 'l tempo fama, onor, forza e ingegno;

co 'l tempo gioventù e beltà more;

co 'l tempo manca ciascun erba e fiore,

co 'l tempo ogni arbor torna in secco legno;

co 'l tempo passan guerre, ingiurie e sdegno;

co 'l tempo fugge e parte ogni dolore;

co 'l tempo il tempo chiar s'inturba e bruna;

co 'l tempo ogni piacer finisce e stanca;

co 'l tempo il mar tranquil dà gran fortuna;

co 'l tempo in acqua vien la neve bianca;

co 'l tempo perde il suo splendor la luna.

Ma in me già mai l'amor co 'l tempo manca.

Las traducciones e imitaciones ibéricas del soneto de Calmeta son todas de la segunda mitad del siglo XVI. Es imposible establecer un orden cronológico. Pero es fácil suponer que la primera que se hizo gozó de tal éxito, que la gente la sabía de

\footnotetext{
${ }^{4}$ Girolamo Angeriano, égloga De obitu Lydiae (1520), según Joseph G. Fucilla, Estudios sobre el petrarquismo en España, 215.

${ }^{5}$ Vincenzo Colli, llamado "il Calmeta" (m. 1508), según Fucilla, Estudios sobre el petrarquismo en España, 96. Este soneto, y también el de Panfilo Sasso que se verá en la página 32, se atribuyeron a Serafino Aquilano (o dall'Aquila), quizá porque este contemporáneo de Angeriano y de Calmeta compuso varios strambotti u octavas sobre el mismo tema: "Se 'l tempo spiana ogni superba altezza / et ogni gran signor converte in polve..."; "Consuma el tempo ogni aspro e duro sasso, / poi lo converte in polve a poco a poco...", "Co 'l tempo al fier caval si mette il freno..." (Die Strambotti des Serafino dall'Aquila, núms. 215 a 217).
} 
memoria, con las lagunas y las equivocaciones de rigor, y que estas fueron llenándose o corrigiéndose de la manera que cada cual pudo. ${ }^{6}$

He aquí una traducción (anónima) que sigue muy de cerca el texto de Calmeta:
[1] Con tiempo pasa el año, el mes, la hora; con tiempo el reino, imperio y la riqueza; con tiempo fama, ingenio y fortaleza; con tiempo lo hermoso se desdora; con tiempo el prado verde se desflora; con tiempo muda el árbol la corteza; con tiempo pasan guerras y crüeza; con tiempo va el dolor adonde mora; con tiempo el tiempo claro se escurece; con tiempo el pasatiempo ha fin y estanca; con tiempo el mar tranquilo se embravece; con tiempo el agua es vuelta en nieve blanca; con tiempo el sol se eclipsa y esclarece. Mas no con tiempo amor de mí se arranca. ${ }^{7}$

\section{He aquí otro texto:}

[2] Con tiempo el año, el día, el mes, la hora, con tiempo reino, imperio y fortaleza, con tiempo fama, ingenio y gallardía $[$ sic! $] \ldots$

\footnotetext{
${ }^{6}$ Carolina Michaëlis de Vasconcelos editó y estudió algunas de las traducciones portuguesas y castellanas en sus "Notas aos Sonetos anónimos", 110-118, en sus "Investigações sobre sonetos e sonetistas portugueses e castelhanos", 544 y 545, y en las pp. 86-89 de su edición del Cancioneiro de Fernandes Tomás.

${ }^{7}$ Cancionero de poesías varias (manuscrito 617 de la Biblioteca Real), núm. 408. Corrijo el texto que dan los editores para el v. 10 "con tiempo él pasa tiempo a fin y estanca"; pasatiempo es traducción de piacer; en ese mismo verso, estanca ('cansa') es italianismo crudo.
} 
Se parece mucho al anterior, pero lo afean las erratas; no solo gallardía (que no rima con -eza), sino también "el bello claro", v. 9 (por "el tiempo claro") y "nieve fría" (por "nieve blanca"); la variante del v. 13 ("se eclipsa y no parece") no es propiamente errata; puede ser señal de que el copista no tenía ante los ojos un modelo, sino que escribía de memoria. ${ }^{8}$

El soneto que sigue está menos cerca del original de Calmeta (y de la versión [1]):

[3] Con tiempo pasa el año, mes y hora;

con tiempo pasa el mando y la riqueza;

con tiempo, fama, honra y fortaleza;

con tiempo la belleza se desdora;

con tiempo, el que es alegre gime y llora;

con tiempo pierde el árbol la corteza;

con tiempo quita el bien naturaleza;

con tiempo, el que es servido a otro honora;

con tiempo no da luz la blanca luna;

con tiempo es duro hielo el agua clara;

con tiempo el cielo de color se esmalta;

con tiempo, en mar tranquilo hay gran fortuna;

con tiempo deja el sol su curso y pára.

Y en mí [nunca] el amor, con tiempo, falta. ${ }^{9}$

${ }^{8}$ Biblioteca Nacional de Madrid, manuscrito 3915 (Cancionero de Jacinto López), fols. 8v-9r; soneto editado por Raymond Foulché-Delbosc, "136 sonnets anonymes”, núm. 106, y copiado por Joseph G. Fucilla, Estudios sobre el petrarquismo en España, 303. El v. 10 dice: "con tiempo el fuerte tiempo siempre estanca"; quizá el copista no entendió el italianismo estanca, y vio al tiempo como un poderoso torrente de agua que, con el tiempo, acaba por estancarse.

9 "Soneto de Navarro", en las Flores de baria poesía, recoxida de varios poetas españoles ("recopilóse en la ciudad de México año del nasçimiento de Nuestro Salvador Iesuchristo de 1577"), manuscrito 2973 de la Bibl. Nacional de Madrid, p. 325. Este manuscrito está muy corroído por la tinta (hecha tal vez a base de huizache), y lo todavía legible fue copiado a principios del siglo pasado por Antonio Paz y Mélia; esta copia (manuscrito 7982 de la misma Biblioteca) sirvió para la edición de Margarita Peña, México, 1980, núm. 293; evidentemente, el benemérito Paz y 
[4] Con tiempo pasa el año, mes y hora;

con tiempo pasa el mundo [sic] y la riqueza;

con tiempo pasa fama y fortaleza;

con tiempo, el que es alegre gime y llora;

con tiempo, cubre noche clara aurora... ${ }^{10}$

Según parece este texto es copia de otro en que se omitió el verso 4 ("con tiempo la belleza se desdora"), de manera que el verso 5 pasó a ser 4; y, por falta del 5, hubo que inventar otro: "con tiempo, cubre noche clara aurora". Lo demás es casi igual al texto [3], pero con erratas: además de mundo en vez de mando (v. 2), hay aurora en vez de luna (v. 9), calor en vez de color (v. 11) y grande en vez de gran (v. 13); el v. 14 está bien: "Y en mí nunca el amor con tiempo falta".

[5] Con tiempo pasa el año, mas la hora; con tiempo pasa el reino y la riqueza... ${ }^{11}$

Fuera de las dos variantes señaladas (y el mas parece mala lectura por mes), los cuartetos son los del texto [1], pero los tercetos son otros, hechos expresamente para rendir homenaje a la reina de Francia:

...con tiempo, tras la aurora noche escura;

con tiempo, el que cantaba presto llora;

fuerza, gloria y valor, todo perece.

Mélia no "reconstruyó" bien el último verso: leyó mismo, pero lo que hay que leer es nunca.

${ }^{10}$ Carolina Michaëlis de Vasconcelos da noticia de este texto en "Notas aos Sonetos anónimos", 116.

11 "Soneto de la reina [de Francia]", en La silva curiosa de Julián Íñiguez de Medrano, Paris, 1608, 84 (la $1^{\text {a }}$ ed. es de París, 1583). Foulché-Delbosc lo reproduce en "136 sonnets anonymes", 387. 
Pero la voluntad sincera y pura

de servir a mi reina y mi señora, en despecho del tiempo, siempre crece.

El soneto siguiente:

[6] Con tiempo pasa el año, mes y hora...,

se parece al [4] hasta el verso 6, pero se aparta de él a partir del 7 , en busca de una nueva conclusión. El autor, prolífico fabricante de versos ascéticos y piadosos, quiere llevar el agua a su molino, que es excitar al pecador al arrepentimiento:

... con tiempo pierde el tigre la braveza, con tiempo lo que es malo se mejora;

con tiempo el tiempo se consume y anda;

con tiempo se va y viene la fortuna

y con tiempo la luna mengua y crece;

con tiempo lo que es duro más, se ablanda

y con tiempo lo blando se endurece:

¡y no hay, con tiempo, en ti mudanza alguna! ${ }^{12}$

Estos dos últimos sonetos toman el impulso del soneto original, pero lo alteran, introduciendo nuevas imágenes. Lo mismo, y de manera más acentuada, se observa en los cinco siguientes. El primero es de Camões:

[7] O tempo acaba o ano, o mês e a hora;

a força, a arte, a manha, a fortaleza;

o tempo acaba a fama e a riqueza;

o tempo o mesmo tempo de si chora;

${ }^{12}$ Juan López de Úbeda, "Soneto al alma obstinada", en su Vergel de flores divinas, fol. 181r. 
o tempo busca e acaba a onde mora qualquer ingratidão, qualquer dureza, mas não pode acabar minha tristeza enquanto não quiserdes vós, senhora.

O tempo o claro dia torna escuro, e o mais ledo prazer em choro triste; o tempo a tempestade em grã bonança.

Mas de abrandar o tempo estou seguro o peito de diamante, onde consiste a pena e o prazer desta esperança.

El soneto que sigue es anónimo:

[8] Con el tiempo se pasan meses, días; con el tiempo se acaba la riqueza; con el tiempo, la fama y fortaleza; con el tiempo, gentiles gallardías; con el tiempo, las fiestas y alegrías; con el tiempo, el dolor y la tristeza; con el tiempo, del tiempo el aspereza; con el tiempo, desdenes, demasías; con el tiempo se pierde el tiempo bueno; con el tiempo se muda la fortuna; con el tiempo, en el mar viene bonanza; con el tiempo se hace el malo bueno; con el tiempo su luz pierde la luna. Mas no hará en mi amor tiempo mudanza. ${ }^{13}$

El tercero es de Baltasar Estaço:

[9] Co tempo o prado seco reverdece; co tempo cai a folha ao bosque umbroso;

${ }^{13}$ Flores de baria poesía (véase supra, nota 8), 326; M. Peña (ed.), núm. 294. 
co tempo pára o rio caudaloso;

co tempo o prado pobre se enriquece;

co tempo um louro morre, outro florece;

co tempo um é sereno, outro invernoso;

co tempo foge o mal duro e penoso;

co tempo torna o bem, já quando esquece;

co tempo faz mudança a sorte avara;

co tempo se aniquila um grande estado,

co tempo torna a ser mais eminente;

co tempo tudo anda e tudo pára.

Mas só aquele tempo que é passado

co tempo se não faz tempo presente. ${ }^{14}$

\section{El cuarto es de Lope de Vega:}

[10] Con el tiempo se pasan horas y años;

con el tiempo el mayor reino perece;

con el tiempo el ingenio desfallece,

con el tiempo la guerra y los engaños;

con el tiempo da el tiempo desengaños;

la beldad con el tiempo se envejece;

con tiempo merma el mar, con tiempo crece,

y con el tiempo acaban nuestros daños;

con tiempo el mar sereno dio fortuna;

con tiempo cae la máquina más alta,

y nos da el tiempo sepultura y cuna;

${ }^{14}$ Baltasar Estaço, Sonetos, canções, églogas, fol. 33r. El Visconde de Juromenha atribuyó este soneto a Camões (1861); figura también en la edición de Lírica completa de Camões por Ma. de Lourdes Saraiva, Lisboa, 1980, 450, aunque ella misma advierte: "Nenhum dos editores modernos o inclui". -La partícula co es contracción de com $o$. 
el tiempo seca el campo y él le esmalta;

con el tiempo se eclipsan sol y luna.

Y en mí jamás amor con tiempo falta. ${ }^{15}$

Podrá observarse cómo en los tercetos (versos 9-14) hay claras reminiscencias de los versos 11, 12 y 14 del texto [3].

En cambio, en el "Soneto al tiempo de Couarruuias" ( $¿ S e-$ bastián de Covarrubias, el lexicógrafo?) casi no queda de Calmeta sino la idea general:

[11] El tiempo el duro mármol va ablandando;

el tiempo va la guerra feneciendo;

el tiempo va la nieve deshaciendo;

el tiempo las riquezas va gastando;

el tiempo va la fuerza aniquilando;

el tiempo la verdad va consumiendo;

el tiempo hasta el sol va escureciendo;

el tiempo los colores va quitando;

el tiempo, que da al árbol verde hoja

y le adorna de alegre vestidura,

él mismo de su pompa le despoja;

el tiempo, que da mal y desventura,

ser de ella medicina se le antoja.

Amor solo en mi pecho siempre dura. ${ }^{16}$

${ }^{15}$ Lope de Vega, La serrana de Tormes, 453 y 454; cfr. Otto Jörder, Die Formen des Sonnets bei Lope de Vega, 225, nota, y Joseph G. Fucilla, Estudios sobre el petrarquismo en España, 243.

${ }^{16}$ Biblioteca Nacional de Madrid, manuscrito 3968, fols. 167v-168r. Publicado por Foulché-Delbosc, “237 sonnets”, núm. 171. 
En el soneto de Panfilo Sasso (1455-1527) que copio en seguida han influido evidentemente los mismos pasajes de Ovidio en que se inspiró Calmeta, y también, probablemente, el soneto mismo de Calmeta. Dice así:

Co 'l tempo el villanel al giogo mena

el tor, si fiero e sì crudo animale;

co 'l tempo el falcon si usa a menar l'ale

e ritornar a te, chiamato a pena;

co 'l tempo si domestica in catena

el bizzarro orso e 'l feroce cinghiale;

co 'l tempo l'acqua, ch'è sì molle e frale,

rompe el dur sasso come el fosse arena;

co 'l tempo ogni robusto arbor cade;

co 'l tempo ogni alto monte si fa basso.

Ed io co 'l tempo non posso a pietade

mover un cor d'ogni dolcezza casso:

onde avanza di orgoglio e crudeltade

orso, toro, leon, falcone e sasso. ${ }^{17}$

Es un soneto de esquema distributivo-recapitulativo. Se van enumerando los animales que con el tiempo se amansan - el toro, el halcón, el oso, el jabalí-, a los cuales se añade el poder del agua que horada un peñasco si cae sobre él durante un tiempo, y en el verso final se reúnen todos - aunque con una infracción: en vez del cinghiale ('jabalí') está el león. La última palabra del soneto es sasso, puesta por el poeta como si fuera su firma: [P.] Sasso.

\footnotetext{
${ }^{17}$ Este soneto se atribuyó en un tiempo a Serafino Aquilano, lo mismo que el de Calmeta (cfr. supra, nota 5). De esta falsa atribución se ocupa Mario Menghini en su edición de Le rime de Serafino Aquilano, 213.
} 
Siguen algunas traducciones o imitaciones ibéricas:

Con el tiempo el león, aunque inhumano, se inclina y juega con el leonero; con el tiempo el halcón, aunque muy fiero, en viendo al cazador le va a la mano;

con el tiempo también se van a llano las peñas, que en romperlas son de acero; y el toro al labrador, como un cordero se postra, con el tiempo, sin alano.

Sola Isabel no quiere, ni ella puede, con el tiempo, ablandarse con mi lloro, por más que llore yo y el tiempo ruede.

¿Qué te aprovecha, di, ser como un oro si tu crueldad y tu dureza excede la del león, halcón, peñas y toro? ${ }^{18}$

Aquí, como se habrá visto, no hay ninguna falla en cuanto a la distribución-recapitulación, pero uno de los animales de Sasso, el oso, ha quedado fuera. - Y sigo:

Con el tiempo el villano a la melena obliga al toro, que la frente enriza; con el tiempo el halcón la pluma eriza, y vuela y caza, y vuelve a mano ajena; con el tiempo se rinde a la cadena el oso, y el león que atemoriza, y con el tiempo el agua llovediza vuelve una piedra como blanda arena.

${ }^{18}$ Manuscrito 3915 de la Bibl. Nacional de Madrid (Cancionero de Jacinto López), fol. 11r. (En este manuscrito está una de las versiones del soneto de Calmeta: Cfr. supra, nota 8). Editado por Foulché-Delbosc, "136 sonnets anonymes", núm. 118, 394. 
Y con el tiempo yo mover no puedo un oso, un toro, león, halcón o piedra, donde se ve que su crueldad los vence;

y pues con tiempo, aunque sin tiempo, quedo

desasido del muro como hiedra, mi vida acabe y mi dolor comience. ${ }^{19}$

Es una imitación más rigurosa del soneto de Sasso: los cinco elementos de la comparación reaparecen en la recapitulación, solo que esta no se pone en el verso final, sino en el 10. El siguiente traductor es Manuel de Faría y Sousa:

Com o tempo se vence, do manhoso caçador, qualquer urso mais severo; com o tempo, domado o touro fero nos mostra o campesino artificioso; com o tempo o leão mais ruidoso vencido de uma indústria ver espero; com o tempo se vence o tigre austero porque, enfim, o rendeu trato amoroso;

com o tempo se inclina a águia rapante à regalada mão; a pedra, quanto a fonte nela cai, tanto desmedra.

Vences, ó Albánia (em resistir constante manha, arte, indústria, amor, regalo e pranto), urso, touro, leão, tigre, águia e pedra. ${ }^{20}$

\footnotetext{
${ }^{19}$ Soneto de Lope de Vega, en la Primera parte de las Flores de poetas ilustres de España ... ordenada por Pedro Espinosa, Valladolid, 1605, fol. 117 (y edición de Francisco Rodríguez Marín, 173). Cfr. la nota de Rodríguez Marín, 395 y 396. Otto Jörder, Die Formen des Sonnets bei Lope de Vega, 225, nota, descubrió que ya Lope había incluido este soneto en su comedia El soldado amante, acto II (Obras, ed. de la Academia, nueva serie, tomo 9, 571). Véase Rosa Navarro Durán, "El soneto de Sasso 'Col tempo el villanel al giogo mena' y Lope de Vega", 391-409. —La melena del primer verso es 'cierta piel blanda que se pone al buey en la frente para que no se lastime con el yugo'.

${ }^{20}$ Manuel de Faría y Sousa, Fuente de Aganipe, fol. 151v.
} 
Faría y Sousa era un portugués avecindado en Madrid que en sus obras, muy numerosas, trató de distinguirse superando en ingenio a los grandes poetas españoles que en los tres o cuatro primeros decenios del siglo XVII residían en la Corte. El soneto que he copiado lo pinta muy bien: Faría ha querido hacer un soneto perfecto, superior incluso al original de Sasso. En efecto, el verso 14 de Sasso, el recapitulativo, no obedece el orden en que han aparecido los elementos de la distribución, aparte de que en la distribución hay jabalí y en la recapitulación hay león. En cambio, el verso 14 de Faría recoge las imágenes en el orden en que han aparecido. No solo eso: las imágenes de Sasso son cinco, y las de Faría son 6: oso, toro, león, tigre, águila y piedra. Aún más: el verso 13 enumera, en el orden debido, los medios de que se ha valido el tiempo para conseguir su propósito: la maña del cazador, el arte del campesino, la industria del domador, etc. (Una pequeñez: lo que es fuente en el v. 11 se convierte en llanto en el 13).

En contraste con el soneto de Faría, tan cuidadosamente elaborado, el soneto que comienza "El libre pajarillo se cautiva...", mal atribuido a Lope de Vega, es sumamente torpe: la enumeración incluye un pajarillo que se acostumbra a su jaula, un animal bravío que se amansa, y elementos como el mar, el hielo y el sol, a los cuales cualquiera puede acostumbrarse, mientras que a una mujer nadie la puede forzar si ella no quiere,

que es más furiosa, amando disgustada, que el pájaro, animal, mar, sol y hielo.

Es un soneto peor que mediocre. ${ }^{21}$

${ }^{21}$ Se recita en la comedia El rey por trueque, atribuida a Lope de Vega (Obras, tomo 2, 550), pero que ciertamente no es de él. Cfr. el catálogo de Jörder, Die Formen des Sonnets bei Lope de Vega, núm. 131, y Antonio Carreira, "Algo más sobre textos y atribuciones en la lírica áurea", 51. (Se puede añadir que las hazañas ponderadas por el anónimo poeta no son propiamente del tiempo, sino de la costumbre.) 
Los dos sonetos que siguen sí son de Lope. El primero pone la recapitulación en los versos 9-10, y el segundo prescinde por completo del esquema:

Si gasta el mar la endurecida roca con el curso del agua tierna y blanda; si el español que entre los indios anda, con largo trato, a su amistad provoca;

si al ruego el áspid la fiereza apoca; si el fuego al hierro la dureza ablanda, no yerra Amor cuando esperarle manda un imposible a mi esperanza loca:

que el tiempo que las rocas enternece, indios, áspides, hierros, bien podría sirviendo, amando, cuanto Amor concede

(por más que mi desdicha os endurece), señora, enterneceros algún día: que un inmortal amor todo lo puede..$^{22}$

Sorprende, en esta serie de derivaciones de Sasso, la imagen del indio (americano, por supuesto) cuya amistad logra el español a fuerza de un trato asiduo (como el que se tiene entre amigos). Tampoco es muy convincente la del áspid que apoca su fiereza cuando se lo ruegan.

Rompe una peña el agua cuando estriba por largo curso en ella su corriente, y a la segur del labrador valiente se humilla el pino y la arrugada oliva;

de su fruto el caudal la palma altiva rinde, aunque tarde, a la africana gente;

${ }^{22}$ Lope de Vega, Rimas (1609), en sus Obras poéticas, 41. El "agua tierna y blanda" del v. 2 parece recuerdo de P. Sasso ("acqua molle e frale"). 
viene el novillo al yugo, y la serpiente

a la voz del encanto se derriba;

fabrica un escultor una figura

de un mármol duro, de una piedra helada,

$\mathrm{y}$ viene a tener ser lo que no era.

Y por más que mi amor vencer procura

una mujer hermosa y delicada, con ser mujer, está rebelde y fiera. ${ }^{23}$

Se le puede perdonar a Lope, por ser Lope, que diga oliva (y "arrugada") en vez de olivo, y la imagen de la serpiente (= áspid) es más convincente aquí que en el soneto anterior: se derriba (se queda pasmada, dormida) gracias a la chirimía del encantador. Pero no se puede tolerar que ponga, en serie con fenómenos cotidianos y sujetos al paso del tiempo, el caso excepcionalísimo de Pigmalión: no es cosa de todos los días que los dioses conviertan una estatua en mujer de carne y hueso.

Los versos iniciales del siguiente soneto recuerdan, ciertamente, el comienzo del soneto de Sasso:

Con el tiempo, el novillo no domado sujeta la cerviz 'nel yugo duro; y con el tiempo, el más soberbio muro del mismo tiempo vemos derribado..., ${ }^{24}$

pero no pasa de ahí; el segundo cuarteto describe hazañas mucho menos espectaculares: con el tiempo se aclaran las cosas, de manera que el poeta está seguro de que el tiempo acabará por mostrar "la limpia y pura fe" de su amor.

${ }^{23}$ Lope de Vega, La viuda valenciana, 71.

${ }^{24}$ Manuscrito 4117 de la Bibl. Nacional de Madrid, fol. 32. Lo reproduce H. Boneville en su Guirnalda odorifera (thèse complémentaire), 28 (en el v. 4 escribo del en lugar de do el). 
En su Desengaño de amor en rimas, Pedro Soto de Rojas incluye cinco sonetos sobre el tiempo. Sus epígrafes son: 1, "Todo se muda, su desdicha no"; 2, "Deprecación al tiempo"; 3, "Potencia del tiempo, frustrada en su amor"; 4, "Caída miserable", y 5, "Fénix perjura". ${ }^{25}$ El Desengaño de amor, primer libro de versos de Soto de Rojas, se imprimió en 1623, cuando él ya era un cuarentón. Es un libro ambicioso, con más de doscientas composiciones, muchas de ellas bastante largas. Es imposible que no se haya dado cuenta de que, al publicarlo, iba a competir con toda una pléyade de grandes poetas, con Lope, Quevedo y Góngora a la cabeza; y justamente en el año 1623 la república literaria española había alcanzado su pleno esplendor. Pero él no se amilanó. Más bien, como sucede en los pechos generosos, aceptó la competencia y apostó por la Poesía. Véase, por ejemplo, el comienzo de la "Deprecación al tiempo":

Si quiebras, tiempo, los peñascos duros; si aceros comes, si metales bebes; si firmes montes con tus fuerzas mueves, y a brazos rindes invencibles muros;

si los anfiteatros mal seguros están al golpe de tus filos breves; si Troyas das al viento en polvos leves y Cartagos al suelo en llantos puros, ¡muda aquel pecho...!, etc.

No cabe duda de que estos versos están todavía, aunque ya de manera algo borrosa, dentro de la tradición iniciada por Calmeta y Panfilo Sasso - la fuerza incontrastable del tiempo como tema poético- - pero tampoco cabe duda de que las imá-

\footnotetext{
${ }^{25}$ En la edición de sus Obras por Antonio Gallego Morell llevan, respectivamente, los núms. 12, 76, 87, 152 y 153.
} 
genes de Soto de Rojas son sumamente novedosas: quebrar peñascos, comer aceros, beber (!) metales, sólidos anfiteatros que vacilan al golpe de unos filos breves, y, sobre todo, esas Troyas esparcidas al viento en polvos leves y esas Cartagos derribadas al suelo en llantos puros... Son versos que "suenan" quizá más a Quevedo que a Góngora. En cambio, estos otros, que son el comienzo del tercer soneto:

El ceño arisco de una sierra fría, en el semblante alegre de este llano pudo el tiempo mudar, que tanta mano toda elevada vence valentía;

laurel pomposo, altivo, que solía albergue ser a mucho vuelo ufano, a seco tronco se reduce anciano: convencióle del cierzo la porfía...,

"suenan" más bien a Góngora; el hipérbaton de "tanta mano [o sea, una mano tan poderosa] toda elevada vence valentía" ( $v a$ lentía $=$ cumbre) es muy gongorino, como también el "mucho vuelo ufano" (muchos pájaros bulliciosos), y el tronco del laurel, seco ahora a causa de la "fuerza de convicción" del cierzo...

Los sonetos cuarto y quinto tienen menos relación con el tiempo, pero el primero merece ser citado íntegramente:

Múdase el tiempo y, con mudarse, muda la planta, el animal, el ave, el pece; estrecha a Anfitre y a Anfitrite crece; orna a Cibeles y a Cibel desnuda;

hace que, humilde a tanto imperio, acuda Cáucaso erguido, que inmortal parece; cual sombra todo, vana, desfallece a su cuchilla incontrastable, aguda. 
Este mundo inferior es de una instable forma imperfecta, y cuanto en él se cría imita a su principio varïable.

Sólo es constante la desdicha mía, que, como nace de mi amor durable, no se puede mudar como solía.

Los versos 3 y 4 de este soneto producen en cualquier lector un sobresalto - que es, evidentemente, lo que se propuso el poeta. ¿Por qué Anfitre y Anfitrite?, ¿por qué Cibel y Cibeles? La explicación debe de ser esta: Anfitrite (deidad marina) es la pleamar y Anfitre la bajamar; Cibeles (diosa de la fertilidad) es la naturaleza en verano y Cibel la misma naturaleza en invierno. En una palabra: las mareas y las estaciones están sujetas al ritmo del tiempo. Anfitre y Cibel parecen un chiste, pero el soneto es completamente serio. (Que yo sepa, ningún poeta imitó un "rasgo de ingenio" tan fuera de lo común).

La huella de Sasso sigue siendo visible en este soneto que recita un personaje en la novela pastoril Esperanza engañada, escrita en castellano por un oscuro escritor portugués:

Con el tiempo, la roca más subida su cumbre iguala al más profundo llano, y obedece, doméstica, a la mano, con el tiempo, la fiera embravecida.

La piedra más de Paro endurecida se ablanda, resistiendo al tiempo en vano, y la subida gloria del romano con el devorador tiempo se olvida; con el fuego se ablanda el hierro duro; la nieve se derrite al fuego ardiente; no hay cosa donde no haga el tiempo efeto. 
Mas si eres intratable, ¿qué procuro?:

que, a no ser de las otras diferente,

que amaras, Amarilis, te prometo. ${ }^{26}$

Me detengo en el segundo cuarteto. Hasta aquí, quienes pagan tributo al tiempo han sido objetos naturales, como prados, montes, peñas, árboles, leones, osos,${ }^{27}$ pero algunos poetas mencionan también obras hechas por la mano del hombre, edificios sobre todo: así Angeriano ("Tempore ruunt praetoria..."), y el anónimo que dice que, con el tiempo, “el más soberbio muro / del mismo tiempo vemos derribado", y Soto de Rojas, que evoca a Troya y a Cartago y habla de "anfiteatros" sólidamente construidos, pero "mal seguros" a los golpes del tiempo. Es lo que hace Fernandes Raya al recordar los mármoles de Paro y "la subida gloria del romano", y es lo que hace también el autor del siguiente soneto:

Gasta y consume el tiempo toda cosa;

los altos edificios suntüosos, con los ligeros años presurosos, tienen al cabo fin, que es ley forzosa.

Feneció la memoria valerosa de los varones claros y animosos que quisieron con hechos hazañosos eternizar la fama venturosa.

\footnotetext{
${ }^{26}$ Manoel Fernandes Raya, Esperança engañada, 242; soneto dado a conocer por Antonio Carreira en "Algo más sobre textos y atribuciones en la lírica áurea", 51.

${ }^{27} \mathrm{La}$ imagen del potro que con el tiempo aprende a tolerar el freno está en Ovidio ("pati frena docentur equi"; "paret equus lentis animosus habenis"), pero no en sus imitadores italianos y españoles, con una excepción notable: el soneto de Luis Carrillo y Sotomayor "Al ejemplo de las cosas que fueron y acabaron", 102, "gran soneto" según Gracián (Agudeza y arte de ingenio, discurso II): "El imperioso brazo y dueño airado / el que Pegaso fue...”, etc.: el brioso corcel que aprendió a obedecer y fue un veloz Pegaso ricamente enjaezado, es hoy un triste jamelgo que apenas sirve como bestia de labor, "que el cano tiempo, en fin, todo lo acaba".
} 
El cetro, imperio, mando y monarquía de Troya y Grecia y Roma dio en el suelo: como sombra pasó su señoría.

Sujeto está a la dura tiranía del tiempo cuanto cubre el alto cielo, ¿y no ha de tener fin la cárcel mía? ${ }^{28}$

Pero este soneto no está propiamente en la línea de Panfilo Sasso, sino más bien en la de Baldassare Castiglione, que, a diferencia de Sasso, evoca solo la magnificencia de la antigua Roma, reducida a cenizas por la envidia del tiempo:

Superbi colli, e voi, sacre ruine, che 'I nome sol di Roma ancor tenete, ahi, che reliquie miserande avete de tant' anime eccelse e pellegrine!

Colossi, archi, teatri, opre divine, trionfal pompe gloriose e liete, in poco cener pur converse siete, e fatte al vulgo vil favola al fine.

Cosi se ben un tempo al tempo guerra fanno le opre famose, a passo lento e l'opre e i nomi il tempo invido atterra.

Vivrò dunque fra miei martir contento, che se 'l tempo dà fine a ciò ch'è in terra, darà forse ancor fine al mio tormento.

Castiglione termina, como Sasso, con una "aplicación" a su estado sentimental (real o imaginario); pero si su soneto fue

${ }^{28}$ Soneto atribuido a Francisco de Figueroa (uno de los varios poetas españoles que merecieron el epíteto de "divino"), pero declarado apócrifo por su último editor, Chirstopher Maurer, en su Obra y vida de Francisco de Figueroa. (Lo cual no significa, o no debiera significar, que el soneto sería mejor de lo que es si alguien reivindicara su autenticidad). 
aplaudido e imitado no solo en España, sino en toda la Europa renacentista, ${ }^{29}$ fue por su evocación de las soberbias siete colinas, cubiertas de colosos, arcos, teatros, obras divinas. Un paso más, ya en los tiempos barrocos, y nos encontramos ante un soneto de Lodovico Paterno, que explota a conciencia el recurso de la enumeración. Su soneto "Se colonne, trofei, tempi, archi e fori, / stagni, terme, acquedotti, are e teatri...", fue traducido así por Cristóbal de Mesa:

Teatro, capitolio, coliseo, colunas, arcos, mármoles, medallas, estatuas, obeliscos y murallas do vencieron las obras al deseo;

templos, carros triunfales, gran trofeo de reinos, de victorias y batallas, colosos, epitafios, antiguallas de los sepulcros, que desiertos veo;

pirámides, pinturas, termas, baños, reliquias y ruïnas de la pompa del edificio de la antigua Roma:

Si puede tanto el curso de los años, podrá ser que también el tiempo rompa mi mal, pues toda cosa acaba y doma. ${ }^{30}$

Y entonces un "Incógnito" se propuso superar a Paterno, o a Mesa, o a ambos, de la manera siguiente:

${ }^{29}$ Véase la antología Fiori di sonetti / Flores de sonetos, Antonio Alatorre (ed.), xxix-xxxi y 74-77.

${ }^{30}$ Fiori di sonetti / Flores de sonetos, 78 y 79. La enumeración de Paterno comprende 38 elementos; la de Mesa, solo 22. (El traductor omite por completo la materia del segundo cuarteto del soneto original: cónsules, senadores, tribunos, dictadores, lictores, etc.). 
Coliseos, pirámides, memorias, simulacros, filabres, obeliscos, pináculos, altares, grutas, riscos, termas, efigies, láminas, historias,

lauros, trofeos, vencimientos, glorias, sierras, pizarras, mármoles, pedriscos, rocas, peñascos, cóncavos, mariscos, bandos, guerras, traiciones y vitorias, terraplenos, murallas, galerías, casamatas, mauséolos, colosos, torreones, sepulcros, monumentos, fronteras, fuerte bronce, artillerías, chapiteles, lumbreras, contrafosos, arbolantes, sillares y cimientos, sus firmes fundamentos, el Tiempo, que los hace, los muda, trueca, quita y los deshace. ${ }^{31}$

Obsérvese cómo, a pesar de estar alargado por el estrambote de tres versos, no hay en este soneto la obligada expresión final de algún sentimiento. Además, aquí lo clásico (coliseos, obeliscos, termas...) se mezcla caóticamente con muchas otras cosas, hasta llegar a un total de 48 elementos. Es un soneto de relumbrón.

\section{III}

En esta sección agrupo, en orden cronológico aproximado, algunos sonetos que están fuera de la tradición de Panfilo Sasso y de Calmeta, y que - en apariencia, por lo menos - no tratan de señalarse por vistosos artificios formales. Podría decirse que

31 "Rimas del Incógnito" publicadas por Foulché-Delbosc, 359 y 360 . No sé qué cosa son filabres (v. 2); en cuanto a arbolantes (v. 14), debe ser errata por arbotantes. 
son más "sentidos", más "personales". El desfile comienza con Juan Boscán, patriarca de la poesía española "a la italiana”. Copio solo el comienzo:

El tiempo en toda cosa puede tanto, que aun la fama, por él, inmortal, muere; no hay fuerza tal que el tiempo, si la hiere, no le ponga señal de algún quebranto.

Tiene fin el placer, fenece el llanto; si esto es ansí, ¿por qué mi dolor quiere?.... ${ }^{32}$

Jorge de Montemayor parece recordar unas sentencias famosas del Eclesiastés, capítulo 3: "Omnia tempus habent..., tempus flendi et tempus ridendi, tempus plangendi et tempus saltandi..., tempus acquirendi et tempus perdendi...", etc.:

Del tiempo se haría larga historia, considerando bien su movimiento: el tiempo da tristeza y da contento, abre la puerta y cierra a cualquier gloria;

el tiempo pone y quita en la memoria amor y desamor, gloria y contento; el tiempo abaja y alza el pensamiento; $\mathrm{y}$ al que es vencido ayer, hoy da vitoria; si el tiempo enoja hoy, mañana aplace; finge su vía incierta y presurosa, y lo que hizo ayer, hoy es deshecho.

En toda parte el tiempo hace y deshace, y nunca veo que en mí deshizo cosa; mas ¿cómo deshará donde no ha hecho? ${ }^{33}$

${ }^{32}$ Cancionero de poesías varias (manuscrito 617 de la Biblioteca Real), núm. 402; los editores parecen no haberse dado cuenta de que el soneto es de Boscán; está en sus Obras poéticas, 184.

${ }^{33}$ Jorge de Montemayor, Cancionero (1562); cito por su Poesía completa, 542. 
Soneto atribuido (sin mucho fundamento) a Francisco de Figueroa:

Pudieras, tiempo, estar ya satisfecho, bañado en sangre de mis propios daños, viéndome puesto en desamor y engaños y en esta ausencia, do me ves, deshecho, sin dar cansancio al encerrado pecho con nuevo aumento en desterrados años, mostrándome tardíos desengaños, pasada la ocasión de su provecho.

Las vanas esperanzas que me diste, las dulces voces con dolor gustadas, señales no entendidas de dolencia,

ligero tiempo, caro las vendiste; y agora al doble me serán contadas, ausente, con amor y competencia. ${ }^{34}$

\section{Juan de la Cueva, soneto “A Baltasar del Alcázar":}

Con el tiempo huyendo van mis años, mi vida consumiendo poco a poco, acompañados de un extremo loco que de un daño me lleva a muchos daños.

Vuelvo la vista atrás, veo los engaños que entre las manos, como ciego, toco; ni aspiro a bien, ni a la razón invoco que me ampare de riesgos tan extraños.

Cfr. también sus octavillas "Contra el tiempo" en la misma edición, 1253-1257: "Pues el tiempo es tan crüel, / y el bueno tan poco dura, / en tan buena coyuntura / digamos mil males de él...”.

${ }^{34}$ Este soneto está en la misma situación que "Gasta y consume el tiempo toda cosa..."; véase supra, nota 28. 
Dame conocimiento la experiencia del cierto fin, si no prevengo en tiempo que no haga su efecto quien me sigue.

Ved, señor, vos, mi aprieto y contingencia, ¿y qué puedo hacer, si Amor y el Tiempo de por sí cada uno me persigue? ${ }^{35}$

Damián de Vegas, en su soneto "Al tiempo mal gastado", no habla como un desdichado en amores, sino como un cristiano que toma en serio la justicia de Dios:

Cuando me tomo algunas veces cuenta del gasto de mi tiempo y de mi vida, hallo, bien liquidada y recorrida, ser de ciento alcanzado en los noventa;

$\mathrm{y}$, no teniendo algún caudal o renta de qué ir pagando deuda tan crecida, consumo el resto, y el pagar se olvida, y así siempre el alcance se acrecienta.

¡Ay, plega a aquel Acreedor Eterno, mientra el último plazo se me cierra, me tome cuenta su sabiduría!,

pues claro está que muy mejor sería pagarlo con el cuerpo acá en la tierra que no con cuerpo y alma en el infierno. ${ }^{36}$

${ }^{35}$ B. J. Gallardo, Ensayo de una biblioteca ..., tomo 2, columna 675.

${ }^{36}$ Damián de Vegas, Libro de poesía christiana, moral y divina, Toledo, 1590; soneto reproducido en el Cancionero y romancero sagrados de Justo de Sancha, 508. El comienzo es reminiscencia de Garcilaso, "Cuando me paro a contemplar mi estado / y a ver los pasos por donde he venido, / hallo que...". También está impregnado de ascetismo cristiano un soneto anónimo del Cartapacio poético del Colegio de Cuenca, 93: "¡Oh tiempo varïable que, huyendo, / al seso engañas del que más lo alcanza..." (o sea: 'engañas la inteligencia del más sagaz'). Y Cfr. Alonso de Ledesma, "Difinición del tiempo", en sus Conceptos espirituales (1600): “Tiempo, estimado de sabios / y desechado de necios...". 
He aquí ahora un soneto anónimo de reflexión "filosófica":

Mostrando está o tempo variedades, por onde o que se perde não se alcança; todo o mundo é composto de mudança, tomando sempre novas qualidades.

Continuamente vemos novidades diferentes em tudo da esperança; do mal ficam as mágoas na lembrança, e do bem, se algum passou, as saudades.

O tempo cobre o chão de verde manto que já coberto foi de neve fria, e em mim converte em choro o doce canto;

e, afora este mudar-se cada dia, outra mudança faz de mor espanto: que não se muda já como solia. ${ }^{37}$

El mensaje de este otro tiene una tonalidad parecida:

Vejo que em tudo o tempo faz mudança: que muda tudo e que nada assegura; o menos firme vejo que mais dura; e quem menos merece, mais alcança.

O triste só no tempo tem sperança; o tempo vem e muda sua ventura; de baixo estado sobe a gran altura; acaba-se a tormenta; vem bonança.

${ }^{37}$ Cancioneiro de Cristóvão Borges, núm. 112. Este soneto se ha atribuido a Diogo Bernardes, y también a Camões. Manuel de Faría y Sousa lo incluye en su edición de las Rimas varias de este poeta (Lisboa, 1685) con un comentario exorbitante: "¡Viva todo el Parnaso, que desde sus fundamentos hasta hoy no se escribió soneto igual a éste! Pesa mil arrobas de majestad, de elegancia, de imágenes y de bellezas. Su argumento es la instabilidad de todo lo de que se compone este miserable mundo. No sabe decir esto con tal limpieza sino quien lo tiene bien trillado con profundísima ponderación". 
Eu só sou que do tempo nada espero, pois tanto tempo há já que o mesmo tempo nem fortuna puderam remediar-me.

Tristeza tomo enfim por passatempo; tristeza em mim só ha, tristeza quero; quem não for triste, não podrá alegrar-me. ${ }^{38}$

En el soneto precedente se lee que el tiempo convierte en lágrimas el dulce canto; en este, en cambio, el poeta dice que el tiempo todo lo cambia, menos su íntima tristeza (reminiscencia, tal vez, del "praeterquam curas attenuare meas" de Ovidio), pero es una tristeza gozosamente asumida. (En la España del siglo XVII los portugueses tenían fama de excesivamente "sentimentales").

Siguen aquí varios de los poetas más ilustres de los Siglos de Oro, comenzando con Cristóbal de Virués:

¡Vario y ligero tiempo! Corre, vuela, y llévame tras ti donde quisieres.

Cayó la suerte. Iré por donde fueres. Engólfate, que sigo a remo y vela.

Dejar dulce quietud enoje y duela; perdidas esperanzas den placeres cuales tú sueles dar. Muestra quién eres en todo cuanto al alma desconsuela:

que, alzando el pensamiento reportado al reino donde tú no tienes parte y donde espero yo tener un grado,

${ }^{38}$ Cancioneiro de Évora, 118 . He retocado los versos 5 y 14, que en el original dicen esperança y poderá respectivamente, a sabiendas que sperança y podrá no son formas portuguesas. En el Cancioneiro de Corte e de magnates, núm 229, se halla este mismo soneto, con texto aún más defectuoso, y con esta terminación: "Fortuna em mim, só a fortuna quero; / fortuna tomo enfim por passatempo, / e quem não for triste não poderá alegrarme”. 
no me espanta el seguirte, aunque me aparte

tu leve curso del sosiego amado

y me vuelva al rigor del fiero Marte. ${ }^{39}$

Vienen en seguida los hermanos Argensola. Primero el mayor, Lupercio:

Yo quise contra el tiempo formar guerra, haciendo (mal su grado) larga historia de aquellos cuya célebre memoria en sordo olvido, sin honor, encierra;

$\mathrm{y}$, como el pensamiento humano yerra, esto me aseguraba la victoria; y yo, con presunción y vanagloria, volaba ya muy lejos de la tierra;

pero, envidiando Amor la guerra ajena, prendióme $\mathrm{y}$, con eterna servidumbre, mi pluma ha dedicado a su alabanza.

Limar pudiera el tiempo mi cadena, pero no quiere usar de su costumbre conmigo, por tomar también venganza. ${ }^{40}$

Y luego Bartolomé, el menor:

Fabio, las esperanzas no son malas; mas tú con tanto aplauso las aceptas, que a oráculos forzosos de profetas, $\mathrm{y}$ aun a vivos efectos, las igualas.

Sabe que contra el tiempo se arma Palas, contra sus inconstancias y sus tretas;

${ }^{39}$ Cristóbal de Virués, Obras trágicas y líricas, fol. 204v. Para entender bien el soneto importa saber que Virués era militar de profesión, de manera que estaba sujeto al rigor de Marte y añoraba una vida tranquila.

${ }^{40}$ Lupercio Leonardo de Argensola, Rimas, 62. 
que él es tal, que tropieza en sus muletas

cuando le piden que use de sus alas.

Y así, nunca en el término futuro

(ni en el presente, si eres sabio) digas

que hay tiempo que del tiempo está seguro:

que cuando, a fuerza de sufrir, le obligas

a que acuda fiel, te pone un muro

de presto entre la hoz y las espigas. ${ }^{41}$

Sobre la velocidad y el silencio con que corre el tiempo medita Góngora en uno de sus últimos sonetos. La rapidez de una flecha al "morder" el blanco, y el silencio con que un carro agonal (en el circo romano) da vuelta a la meta sin rozarla, son menos que la rapidez y el silencio del correr del tiempo:

Menos solicitó veloz saeta destinada señal, que mordió aguda; agonal carro por la arena muda no coronó con más silencio meta, que presurosa corre, que secreta, a su fin nuestra edad. A quien lo duda (fiera que sea de razón desnuda), cada sol repetido es un cometa.

Confiésalo Cartago, ¿y tú lo ignoras?

Peligro corres, Licio, si porfías en seguir sombras y abrazar engaños;

mal te perdonarán a ti las horas: las horas que limando están los días, los días que royendo están los años.

Un cometa anuncia desgracias y muertes; y, si bien lo vemos, cada día que pasa es un cometa, cada uno nos acerca más a

${ }^{41}$ Bartolomé Leonardo de Argensola, Rimas, 248. 
nuestra muerte. Cartago es imagen de lo que fue y ya no es. $\mathrm{Li}$ cio es Luis (de Góngora): el poeta habla consigo mismo. Pocas veces se habrá descrito tan eficazmente la acción del tiempo como en el último terceto.

He aquí ahora un buen soneto anónimo, muy gongorino:

Dos leños rotos soy, y ya fui nave que, despreciando el mar osadamente, a los distantes reinos de Occidente fui de ambición, volví de plata, grave.

Otra no ha visto China que se alabe de su vejez; muchas mordió serpiente, pisado escollo, con oculto diente; las que el mar ha sorbido, el mar lo sabe.

Yo vi tal vez, en desigual tormenta, ya en el fuego mis velas encendidas, ya apagadas mis velas en el agua.

Burlé del Euro, cuando más se alienta, triunfante en fin, mas no de la que fragua borrasca el tiempo en daño de las vidas. ${ }^{42}$

Juan de Arguijo se dirige así "A don Fernando de Saavedra":

Mira con cuánta prisa se desvía de nosotros el sol al mar vecino, y aprovecha, Fernando, en tu camino la luz pequeña de este breve día,

42 "A la fuerça del tiempo", manuscrito 3794 de la Bibl. Nacional de Madrid, fol. 31. Algunas explicaciones: v. 1, ya: ‘en otro tiempo'; v. 4: 'partí cargado de ambición, regresé cargado de plata'; vv. 6-7: '[sobreviví a] muchas naves que murieron mordidas, como por una serpiente, por el diente oculto de un escollo' (en la Soledad $I I$, vv. 317-327, habla Góngora de un arroyo que corre como sierpe y que muerde el pie de un pino que se le atraviesa); v. 9 tal vez: 'algunas veces'; v. 12: el Euro es un viento borrascoso. 
antes que en tenebrosa noche fría pierdas la senda y de buscarla el tino, $y$, aventurado en manos del destino, vagues errando por incierta vía.

Hágante ajenos casos enseñado, y el miserable mal de tantos pueda, con fuerte ejemplo, apercibir tu olvido.

Larga carrera, plazo limitado tienes; veloz el tiempo corre, y queda sólo el dolor de haberlo mal perdido. ${ }^{43}$

\section{Cristóbal Suárez de Figueroa:}

¡Oh tú, de lo crïado horrible guerra, sutil ladrón de fuerzas y hermosura! ¡Tú que deshaces tanta piedra dura, con ser sólidos huesos de la tierra!

No está en su centro tan tenaz la sierra más eminente en ámbito y altura, cuanto te muestras hoy con mi ventura, gigante a quien tu dilación atierra.

$\mathrm{Tu}$ curso aliente del vivir la lumbre, pues, para que el dolor no la consuma, de tu velocidad basta un asomo.

Mas sordo sigues, tiempo, tu costumbre: con quien te huye, leve como pluma; con quien te llama, torpe como plomo. ${ }^{44}$

${ }^{43}$ Juan de Arguijo, Obra poética, núm. LIV.

${ }^{44}$ Cristóbal Suárez de Figueroa, El pasajero, 519 y 520. (Soneto recitado por "el Doctor", que antes ha dicho: "me quejé una vez de la pereza del tiempo, en esta forma"). 
Luis Martín de la Plaza tradujo el soneto "Al tempo" de Torquato Tasso: "Vecchio ed alato dio, nato co '1 sole / ad un parto medesmo con le stelle...": 45

¡Decrépito (si alado) dios, nacido de un parto con el Sol, con las estrellas, y al rapto movimiento de él y de ellas perpetuamente, sin cansarte, asido!

Con tácito poder, con pie atrevido, cuantos ya levantaste imperios huellas, y en profunda región de olvido sellas memorias que burlaban del olvido.

Tú, pues, tiempo, cancela una enemiga memoria que me aflige: a tu victoria añada triunfo y acreciente palma.

Mas en vano mi ruego te fatiga: que, vinculada al alma, esta memoria ha de vivir cuanto viviere el alma. ${ }^{46}$

El correr del tiempo es tema que aparece varias veces en los llamados "poemas metafísicos" de Quevedo: "Vivir es caminar breve jornada...", "Huye sin percibirse, lento, el día...", “¡Ah de la vida! ¿Nadie me responde?...”, con sus memorables tercetos:

${ }^{45}$ Torquato Tasso, Poesie, 797. Cfr. Mario Vitale, "Sul sonetto Al tempo di Torquato Tasso", 36-40. Traduciendo a lenguaje moderno las palabras de Tasso, diríamos que el Tiempo es, en efecto, viejísimo: ¡nació con el Big Bang!

${ }^{46}$ Luis Martín de la Plaza, Poesías completas, 91. (En el v. 3, rapto significa 'rápido': es el "movimiento arrebatado" propio de la esfera de las estrellas fijas en la cosmología ptolemaica). El texto procede del Cancionero antequerano, núm. 280 en la edición de José Lara Garrido; en este mismo Cancionero, núm. 445, hay un soneto anónimo, "La noche oscura, temerosa y fría...", que pondera los cambios que acarrea el paso del tiempo, y que termina con este estrambote: "Sólo mis esperanzas / la noche de mi mal, mi pena y muerte / se estarán, por ser mías, de una suerte". 
Ayer se fue; mañana no ha llegado; ${ }^{47}$

hoy se está yendo sin parar un punto; soy un fue, y un será, y un es cansado.

En el hoy y mañana y ayer, junto pañales y mortaja, y he quedado presentes sucesiones de difunto. ${ }^{48}$

La mejor explicación del último verso está en una carta del propio Quevedo (1635): "Hoy cuento yo 52 años, y en ellos cuento otros tantos entierros míos. Mi infancia murió irrevocablemente; murió mi niñez, murió mi juventud, murió mi mocedad; ya también falleció mi edad varonil. Pues ¿cómo llamo vida una vejez que es sepulcro donde yo propio soy entierro de cinco difuntos que he vivido...?", etc. ${ }^{49}$

La atribución a Quevedo del soneto siguiente es sumamente dudosa:

Bien te veo correr, tiempo ligero, cual por mar ancho despalmada nave, a más volar, como saeta o ave que pasa sin dejar rastro o sendero.

Yo, dormido, en mis daños persevero, tinto de manchas y de culpas grave; aunque es forzoso que me limpie y lave llanto y dolor, aguardo el día postrero.

\footnotetext{
${ }^{47}$ Hay un soneto de José Jerónimo Valmaseda y Zarzosa (1660) que comienza: “Ayer pasó, mañana no ha llegado; / el día de hoy no sé cómo le cuente, / pues apenas le llego a ver presente / cuando le debo lamentar pasado..." (B. J. Gallardo, Ensayo..., tomo 4, columna 883); y Quevedo mismo, en el soneto "Fue sueño ayer, mañana será tierra...", comienza así los tercetos: "Ya no es ayer; mañana no ha llegado; / hoy pasa, y es, y fue...".

${ }^{48}$ En el segundo terceto, junto es verbo (yo junto: 'del pañal y la mortaja hago una sola cosa').

${ }^{49}$ Quevedo, Obras en prosa, 1851.
} 
Éste no sé cuándo vendrá; confío que ha de tardar, y es ya quizá llegado, y antes será pasado que creído.

Señor, tu soplo aliente mi albedrío y limpie el alma, el corazón llagado cure, y ablande el pecho endurecido.

Lo publicó Pedro Aldrete, sobrino de Quevedo, en Las tres Musas últimas castellanas (1670), donde hay gran número de poemas apócrifos. Concretamente, este soneto ya se había publicado, con pocas variantes, entre las Obras de Francisco de Figueroa. Pero también la atribución a Figueroa es muy dudosa. ${ }^{50} \mathrm{Si}$ nos atenemos a los hechos, podemos decir con toda tranquilidad que el soneto no tiene padre conocido.

En cambio, no hay dudas sobre la autenticidad de este otro:

¡Cómo de entre mis manos te resbalas! ¡Oh, cómo te deslizas, edad mía!

¡Qué mudos pasos traes, oh muerte fría, pues con callado pie todo lo igualas!

Feroz, de tierra el débil muro escalas, en quien lozana juventud se fía; mas ya mi corazón del postrer día atiende al vuelo, sin mirar las alas.

\footnotetext{
${ }^{50}$ En su edición de Figueroa (citada supra, nota 28), Christopher Maurer expresa algunas "reservas" (137-140) en cuanto a la paternidad de Figueroa - reconoce, por ejemplo, que los versos 10 y 11 suenan más a Quevedo que a Figueroa-, pero a pesar de ellas, dice, "no podemos rechazar la posible autoría de Figueroa". He aquí las variantes del texto atribuido a Figueroa respecto del atribuido a Quevedo: v. 1, "te miro correr"; v. 3, "antes volar"; v. 7, "y siendo fuerza que"; v. 12, "despierte al alma, al corazón manchado / limpie...". Hay que recordar que las Obras de Figueroa se imprimieron por primera vez en 1625 , cuando hacía ya 36 o 37 años que el poeta había muerto. Finalmente, la disposición de las rimas en los tercetos es ajena a la costumbre lo mismo de Quevedo que de Figueroa.
} 
¡Oh condición mortal! ¡Oh dura suerte!, que no puedo querer vivir mañana sin la pensión de procurar mi muerte.

Cualquier instante de la vida humana es nueva ejecución, con que me advierte cuán frágil es, cuán mísera, cuán vana.

Sin duda Carrillo Sotomayor tenía presente el soneto anterior al escribir este:

¡Con qué ligeros pasos vas corriendo! ¡Oh, cómo te me ausentas, tiempo vano! ¡Ay de mi bien y de mi ser tirano, cómo tu altivo paso voy sintiendo!

Detenerte pensé, pasaste huyendo; seguíte, y ausentástete, liviano; gastéte a ti en buscarte ¡oh inhumano!; mientras más te busqué, te fui perdiendo.

Ya conozco tu furia; ya, humillado, de tu guadaña pueblo los despojos, ¡oh amable desengaño no admitido!

Ciego viví, y al fin, desengañado, hecho Argos de mi mal, con tristes ojos, huir te veo, y veo te he perdido. ${ }^{51}$

Antonio Enríquez Gómez dice cosas parecidas, pero en lenguaje menos exaltado:

Este que, exhalación, sin consumirse por los cuatro elementos se pasea, palestra es de mi marcial pelea y campo que no espera dividirse.

${ }^{51}$ Luis Carrillo y Sotomayor, Poesie, 102. Soneto elogiosamente citado por Gracián, Agudeza, discurso V. 
Voyle siguiendo, y sígueme sin irse;

voyme quedando, y por quedarse emplea

su mismo vuelo, y hallo que desea

ir y quedarse, y con quedar partirse.

Mi error me dice que su rapto apruebe;

pero ¿dónde camino, si su esfera

casi lo eterno con las alas mueve?

No me atrevo a seguirle, aunque quisiera, que corre mucho, y temo que me lleve en el último fin de la carrera. ${ }^{52}$

Francisco de Rioja, "A la fugacidad del tiempo":

Como se van las aguas de este río para nunca volver, así los años, y sólo dejan infalibles daños, que reparar no puede voto mío.

Fundamos esperanzas al estío desde el invierno (¡oh ciego error!, ¡oh engaños!), y nos huyen los tiempos por extraños modos, y huye el floreciente brío.

La dulce atrocidad de aquellos ojos, ante quien ya perdí color y aliento, tras sí la lleva a más andar el día.-

Vive tú a la opinión, de honor sediento, que yo al ocio plebeyo viviría si apenas hay, de lo que fui, despojos.

Juan Vélez de Guevara:

${ }^{52}$ Antonio Enríquez Gómez, "Al curso y velocidad del tiempo”, en sus Academias morales de las Musas, Burdeos, 1612. Compárese el segundo cuarteto con el segundo cuarteto del soneto de Carrillo y Sotomayor. El v. 8, "ir y quedarse...", es cita del primer verso de un soneto famoso de Lope de Vega. 
¡Oh, lo que corre el tiempo apresurado!

No hay siglo largo en su distrito breve;

mas ya que tan ligero el curso mueve, ¿cómo parece a todos tan pesado?

¿Qué corto es el vivir más dilatado, y la más grave duración, qué leve!: porque está de las flores y la nieve cerca lo por venir y lo pasado.

Sólo la vida de la muerte dura; $\mathrm{y}$, pues burlan las propias alegrías, escarmienten ajenos desengaños.

Del morir se granjee la ventura, ya que se vive para pocos días, ya que se muere para muchos años. ${ }^{53}$

El siguiente soneto muestra cómo los poetas portugueses cultivaban los mismos tópicos que los españoles:

Tempo, que tão ligeiro te mostraste até que a tantos males me trouxeste! Depois que neles posto me tiveste, como tão vagaroso te mostraste?

Quando te desejei, nunca chegaste; quando te receei, logo vieste; até chegar ao mal sempre correste, e nunca mais um passo te mudaste.

Pior estado não no pode aver, mas a este poderá outrem chegar, segundo estou de mais mal em que te pes [sic];

53 “Al tiempo", en Jardín de Apolo, academia... recogida por don Melchor de Fonseca y Almeida, Madrid, 1655, fol. 33. 
que não tenho de ti já que temer, pois não tenho de ti bem que esperar, por mais voltas que ao mundo e coisas dés. ${ }^{54}$

En esta sección recojo algunos sonetos "de ingenio"; y comienzo con este de Elói de Souto Maior "A um religioso virtuoso e santo":

O tempo as horas em balança lança; pouco dos campos a verdura dura; murcha-se a flor, fica a frescura escura; se a terra fértil fruito alcança, cança.

A vida ao som desta mudança dança quando por regra de natura atura, até que a morte, com brandura dura, torna a soberba dos que amansa, mansa.

Estáveis cá entre nós vivendo, vendo da morte (ó Ignácio) o desconcerto certo, da vida incerta o emprestado estado.

Em vós a glória, que eu pretendo, tendo, vereis o que vos tinha esperto, perto: sereis, pois sois de Deus chamado, amado. ${ }^{55}$

El soneto "en eco" es un juego típicamente ibérico, aunque con vagos antecedentes en Italia. En cambio, los orígenes italianos del artificio que en seguida va a verse son mucho más claros. Podría decirse que se trata de una forma complicada del soneto continuo, que es el que tiene solo dos rimas o, más aún,

${ }^{54}$ Cancioneiro de corte e de magnates, núm. 275. Según Askins, el autor podría ser Felipe de Aguilar.

${ }^{55}$ Jardim do ceo... [por] Eloyo Saa Souto Mayor, Lisboa, 1607, último folio. 
palabras-rimas (vida/muerte, noche/día, fuego/nieve, etc.) a lo largo de todo el soneto; la "complicación" consiste en meter en el interior del verso una de esas dos palabras cuando no está sirviendo de rima. Por ejemplo, Giuseppe Gosellini comienza así un soneto:

La vita, Amor ch'io vivo è proprio morte, anzi peggior che morte è la mia vita: suol finir morte una penosa vita, ma la mia vita non ha fin per morte...,

pero no mantiene el juego en los diez versos restantes, como lo hacen, en cambio, varios poetas españoles, uno de ellos Baltasar del Alcázar:

Gloriosa pena y mi penosa gloria, tu grande gloria trae al hombre en pena; no pido gloria en nombre de mi pena, mas que a mi pena mires de tu gloria...,

y así hasta el final:

Mas si es que en pena ha de incurrir tu gloria, por que tu gloria se honre con mi pena, ¡muera en mi pena y vivas en tu gloria!

Tal es la estructura de un soneto en que el Tiempo se dirige a nosotros exigiéndonos, implacablemente, cuenta del empleo que hemos hecho de él. De la fama de este soneto son testimonio los muchos manuscritos en que fue copiado. ${ }^{56} \mathrm{He}$ aquí los principales:

${ }^{56}$ Varias de las noticias que recojo proceden de A. L.-F. Askins, nota al núm. 318 del Cancioneiro de Corte e de magnates, y de Antonio Carreira en Voz y Letra, vol. 1, 1990, núm 2, 96. 
1, Biblioteca Nacional de Madrid, manuscrito 2883 (con apostilla marginal, de letra más tardía: "de Lope de Vega”); publicado por Joseph G. Fucilla en Hispanófila, 1962, núm. 16, pp. 106-109;

2, Ibidem, manuscrito 3884, fol. 287 ("Soneto célebre de Lope de Vega"); publicado por Fucilla, loc. cit.;

3, Ibidem, manuscrito 3895, fol. 60v;

4, Ibidem, manuscrito 3992 (¿o 3912?);

5, Ibidem, manuscrito 4140: soneto copiado dos veces en distintas páginas;

6, Biblioteca del Escorial, manuscrito Z.IV.26, fol. 23b;

7, Biblioteca Braidense (Milán), manuscrito AD.XI.57, fol. $26 \mathrm{v}$.

8, Biblioteca Nazionale Centrale, Roma, manuscrito 2.078;

9, Bibliothèque Nationale, París, manuscrito Esp.632 (soneto atribuido a "Almazán");

10, Biblioteca de la Hispanic Society of America, manuscrito CCX en el Catálogo de A. Rodríguez-Moñino y María Brey Mariño, New York, 1965.

11, Arte doctrinal y modo para aprender la lengua matlatzinga, por fray Miguel de Guevara (manuscrito de 1638); es una de las varias poesías que copió el autor en los folios que quedaron en blanco.

A diferencia de lo que hice con los sonetos derivados de Calmeta y de Sasso, en este caso no he creído que valga la pena exhibir paso a paso las diferencias que hay entre los distintos manuscritos; lo que hago es utilizar varios de ellos y elaborar una especie de mosaico. Bien sé que esto es pecar contra las reglas del sacrosanto método filológico, pero aquí el pecado es verdaderamente venial, pues las variantes son muy negligibles: la forma de este soneto es tan estricta, tan trabada, que, por así decir, les deja a los copistas pocas oportunidades de equivocar- 
se o de inventar. Casi puede decirse que los once manuscritos ofrecen un solo texto, que es el siguiente:

Pídeme de sí mismo el tiempo cuenta; si a darla voy, la cuenta pide tiempo: que quien gastó sin cuenta tanto tiempo, ¿cómo dará, sin tiempo, tanta cuenta?

Tomar no quiere el Tiempo tiempo en cuenta, porque la cuenta no se hizo a tiempo; que el Tiempo recibiera en cuenta tiempo si en la cuenta del Tiempo hubiera cuenta.

¿Qué cuenta ha de bastar a tanto tiempo? ¿Qué tiempo ha de bastar a tanta cuenta?: que quien sin cuenta vive, está sin tiempo.

Estoy sin tener tiempo y sin dar cuenta, sabiendo que he de dar cuenta del tiempo y ha de llegar el tiempo de la cuenta.

Las variantes de alguna importancia son poquísimas: v. 1, "Pídeme de mí mismo...", y también "El tiempo de mí mismo..." (mí mismo en vez de sí mismo está en la mayor parte de los manuscritos; pero mismo, en este caso, no va bien con mí: es el Tiempo quien pregunta: "A ver, ¿qué has hecho conmigo?", “¿de qué manera me has empleado?”); v. 3, “pues quien vivió sin cuenta..."; v. 11, “ que al que sin cuenta vive, falta el tiempo", y también "que quien sin cuenta va, le falta el tiempo".

No hay en este soneto nada propiamente religioso, nada específicamente cristiano: la obstinación en el pecado, la justicia divina, la importancia de no dejar el arrepentimiento para la última hora (el "¿Tan largo me lo fiáis?” de Tirso de Molina); $\mathrm{y}$, sin embargo, de alguna manera todo eso está aquí. Es un soneto profundamente serio, aunque el autor se nos muestre mucho más interesado en el juego de ingenio tiempo/cuenta, cuenta/tiempo, que convencido de la importancia de la virtud 
y las buenas obras. Y creo que fue esta doble índole del soneto - mensaje moral a la vez que juego poético — lo que lo hizo tan famoso.

La atribución a Lope de Vega carece de fundamento. Se debe, con toda verosimilitud, al recuerdo de dos sonetos suyos auténticos: "Con el tiempo se pasan horas y años..." y "Con el tiempo el villano a la melena..." (supra, pp. 30 y 33). Más consideración merecen otros epígrafes; "Soneto que embió un amigo christiano al mayor privado del rey de España estando enfermo de una grave enfermedad" (manuscrito 3895), ${ }^{57} \mathrm{y}$ "del duque de Lerma cardenal" (manuscrito 4140, fol. 7r); Askins encontró también el soneto en el Cancionero de príncipes y señores recopilado por Juan Pérez de Guzmán (1892); se atribuye ahí a don fray Garcerán Albanell, arzobispo de Granada, y el título indica que fue enviado al duque de Lerma "después de su caída” (pero Askins no sabe si esto lo dice Pérez de Guzmán o la fuente utilizada por él). ${ }^{58}$ Lo interesante, en todo caso, es que en el manuscrito 3895 hay una "Respuesta del duque de Lerma":

Aunque es razón que dé del tiempo cuenta quien gastó en cuentas largas tanto tiempo, y aunque en la cuenta caigo ya que el tiempo entre los demás tiempos ya me cuenta;

y aunque llegó ya el tiempo de mi cuenta y pierdo ya la cuenta de mi tiempo, por ser tan larga cuenta, en largo tiempo, el que el tiempo cargó sobre mi cuenta,

${ }^{57}$ El "privado" o primer ministro de Felipe III fue, durante veinte años (15981618), el duque de Lerma, paradigma de rapacidad y mal gobierno.

${ }^{58}$ No hay contradicción entre estos epígrafes: Lerma, político "sagaz", previó a tiempo su caída y consiguió que el papa Paulo V lo nombrara cardenal. De no haber sido por esta providencia, quizá hubiera acabado como don Rodrigo Calderón, que en 1621 murió degollado por orden de Felipe IV. 
razón fuera también, quien cuenta tiempo, que en su tiempo tuviera mucha cuenta y avisos diera a cuenta, y no sin tiempo;

y pues que de mi tiempo tuvo cuenta, sepa dar buena cuenta de su tiempo, que de mi cuenta a Dios daré mi cuenta.

Y allí mismo hay "Otro soneto en respuesta":

Quien mide ajeno tiempo y tiene cuenta sólo en la cuenta del ajeno tiempo, mal dará buena cuenta de su tiempo, pues que gastó su tiempo en otra cuenta.

El tiempo pide cuenta, y esta cuenta aprisa se ha de dar del propio tiempo; dará toda su cuenta en pasatiempo el que en ajeno tiempo tuvo cuenta.

Cada cual dará cuenta de su tiempo, y del tiempo no habrá quien no dé cuenta. Nadie tenga su cuenta en otro tiempo, porque si de otro tiempo tiene cuenta, faltarále la cuenta de su tiempo cuando llegare el tiempo de su cuenta.

No es imposible, aunque sí poco probable, que el propio duque haya escrito estas respuestas, o una al menos (y lo mismo da si se la encargó a un secretario); la segunda me parece la mejor: es más unitaria y, sobre todo, el "¡Cuida tu casa y deja la ajena!" es más contundente.

La presencia de este famoso soneto en el Arte manuscrita de fray Miguel de Guevara (1638), en compañía de otro aún más famoso, el "No me mueve, mi Dios, para quererte...", dejó ciego de entusiasmo a Alfonso Méndez Plancarte, patriota de hueso colorado: ¡dos relucientes joyas de la poesía española 
elaboradas en México por un mexicano! Naturalmente, se hace lenguas del segundo, pero del de la cuenta y el tiempo dice que "recata hondura bajo su amanerado alarde preciosista", y que "[no] tendrá rival en nuestro conceptismo, que con él se inaugura". ${ }^{59}$ En descargo suyo — y de Octavio Paz, que se guió por él-, hay que decir que en 1942 se ignoraban muchas cosas que hoy todo el mundo conoce.

En 1665 Juan Caramuel y Lobkowitz incluyó nuestro soneto en su Rhythmica, como ejemplo del fenómeno que él llama unisonantia.

En 1670, dos frailes trinitarios, Bartolomé Serrano y Juan Marcos, emprendieron un viaje a Argel con el fin de rescatar cristianos cautivos; el Libro en que se da la razón del viage que ycimos a la ciudad del Argel es obra de fray Bartolomé, el cual incluye en él un buen número de poesías propias; y entre ellas está el soneto de la cuenta y el tiempo. ${ }^{60}$

A comienzos del siglo XVIII, la Inquisición de México le secuestró al oaxaqueño Manuel del Barrio y Sedano una enorme cantidad de escritos devotos, unos en prosa y otros en verso; entre ellos estaba nuestro soneto. ${ }^{61}$

En 1793, finalmente, cierto fray José Sanz imprimió en Barcelona una obra intitulada El sabio ignorante, en cuyo tomo primero, página 158, está una versión levemente retocada: "Pídeme

${ }^{59}$ Alfonso Méndez Plancarte, Poetas novohispanos, tomo 1, xxxv-xxxvii y 140141. Los dos sonetos ocupan un lugar en la Anthologie de la poésie mexicaine que organizó y publicó Octavio Paz por encargo de la UNESCo (Collection Unesco d'œuvres représentatives, Nagel, Paris, 1952, Série ibéro-americaine 2). En su introducción, p. 20, dice Paz: "Ces quelques poèmes suffisent à faire de Guevara un des plus hauts poètes religieux de la langue". Hay que añadir que ya Marcel Bataillon, en un artículo publicado en la Nueva Revista de Filología Hispánica (vol. 4, 1950), había echado, con mucha discreción, un jarro de agua fría sobre el entusiasmo de Méndez Plancarte.

${ }^{60}$ Bartolomé José Gallardo, Ensayo..., tomo 4, cols. 586-600; el soneto, en la col. 598.

${ }^{61}$ Catálogo de textos marginados novohispanos: Inquisición, siglos XVIII y XIX, núm. 1202.1. 
el Tiempo de sí mismo cuenta, / si darle puedo yo la cuenta al Tiempo...". ${ }^{62}$

Del siglo XVII data una versión portuguesa, atribuida a Martín de Castro de Rio:

Pede-me de si mesmo o Tempo conta, e para dar-se pede a conta tempo, [que] quem viveu sem conta tanto tempo, como dará, sem tempo, tanta conta?

Não quer levar o Tempo tempo em conta, porque conta não fez de dá-la em tempo, posto que para a conta havia tempo, se na conta do Tempo houvesse conta.

Mas que conta dará quem não tem tempo? e em que tempo a dará quem não tem conta?, que [a] quem sem conta vive falta o tempo.

Vejo-me sem ter tempo e sem ter conta, sabendo que hei de dar conta do tempo e que se há de chegar tempo de conta. ${ }^{63}$

Un poeta llamado, al parecer, João Ribeiro, escribió un soneto de conta y tempo para satirizar a quienes, por seguir la moda, gastan su tiempo en hacer sonetos de conta y tempo:

Como poderá dar do tempo conta quem em versos sem conta gasta o tempo?

\footnotetext{
${ }^{62}$ De aquí procede el texto incluido por León María Carbonero en sus Esfuerzos del ingenio literario, 298; y de Carbonero pasó a Agustín Aguilar y Tejera, Las poesías más extravagantes de la lengua castellana, 134.

${ }^{63}$ Cancioneiro de Corte e de magnates, núm 318. Hay otra versión, publicada por Carolina Michaëlis de Vasconcelos en "Notas aos Sonetos anónimos", 113 y 114: "O Tempo já de si me pede conta: / é necessário dar-se a conta a tempo, / que quem gastou...", etc.; el verso 12 dice "Vejo-me sem ter tempo e com ruim conta". (Cfr. supra, p. 31, textos castellanos que comienzan con "El tiempo..." y no con "Pídeme...").
} 
Quem faz sonetos só de conta e tempo será homem do tempo, e não da conta.

Não se pode em tal tempo fazer conta de homens que tão má conta dão do tempo; que, inda que faça deles conta o Tempo, não sabe o Tempo já de quem faz conta.

Não há no mundo conta nem há tempo que possa dar de tanto tempo conta, perdido sempre em conta e sempre em tempo.

Não é o tempo para tanta conta, e quem sente perder sem conta o tempo, porque não gasta o tempo em tempo e conta? ${ }^{64}$

El soneto del tiempo y la cuenta ha tenido no pocas repercusiones o reverberaciones. El autor del que copio en seguida, llamado Pedro da Costa Perestrelo, como si hubiera leído la burla de quienes pierden el tiempo en acomodar tempo/conta y conta/tempo en cada verso, resolvió simplificar la estructura. Hizo un soneto continuo, de solo dos palabras-rimas, pero sin más complicaciones. Así las dos palabras, desligadas del juego, ganan en seriedad. Y el título es muy explícito: "A conta que devemos dar a Deus":

Dos anos mal gastados pede a conta aos mortais o Grão Senhor do tempo; a conta é larga, e tão breve o tempo, que não ousam chegar a lhe dar conta.

A despesa não tem ordem de conta; perdem-se as horas e perdeu-se o tempo,

${ }^{64}$ Publicado por C. Michaëlis de Vasconcelos, "Notas aos Sonetos anónimos", 115 y 116. 
e para se ganhar não é já tempo, que a pressa não lhe deixa dar boa conta.

Culpa é dos homens, mas não é do tempo, em deixar, quando podem, de dar conta, guardando-a por descuido a pior tempo.

A vida corre e não discorre a conta, mas no fim correrá fora do tempo com nome de castigo a não de conta. ${ }^{65}$

La eficacia de una serie de sonetos que vienen en seguida consiste en la simple repetición de la palabra tiempo, sin mención de la idea de "rendir cuentas". Hay un dicho recogido por Gonzalo Correas en su Vocabulario de refranes (1627): “Quien tiempo tiene y tiempo atiende, tiempo viene que se arrepiente", o bien "Quien tiempo tiene y tiempo espera, tiempo viene que desespera" (o "tiempo viene que el diablo le lleva"). A propósito de las expresiones "tiempo y lugar" y "dar tiempo al tiempo", usadas por Cervantes a poca distancia una de otra, su comentarista Francisco Rodríguez Marín recuerda una copla española: "Yo le pedí tiempo al tiempo, / y el tiempo me respondió / que, con el tiempo, tendría / tiempo, lugar y ocasión”, y también una colombiana: "Al tiempo le pido tiempo, / y el tiempo tiempo me da, / y el mismo tiempo me dice / que él me desengañará". ${ }^{66}$

En el siguiente soneto, la palabra tiempo se repite 17 veces:

El tiempo está vengado a costa mía del tiempo que en el tiempo no he mirado: ¡triste de quien del tiempo, en tal estado, el tiempo en todo el tiempo no temía!

Bien me castiga el tiempo la porfía de haberme con el tiempo descuidado,

${ }^{65}$ Soneto publicado por C. Michaëlis de Vasconcelos, "Notas aos Sonetos anónimos", 115.

${ }^{66}$ F. Rodríguez Marín (ed.), El Quijote, Madrid, 1947, tomo 3, 50 y 75. 
pues tan sin tiempo el tiempo me ha dejado, que ya no espero tiempo de alegría.

Pasaron tiempos, horas y momentos en que pude del tiempo aprovecharme para excusar, con tiempo, mis tormentos; mas pues quise del tiempo confiarme, siendo el tiempo de varios movimientos, de mí, que no del tiempo, es bien quejarme. ${ }^{67}$

Hubo una traducción portuguesa del soneto precedente, no muy correcta; por ejemplo, el verso 1 termina "a custa minha", lo cual no rima con las tres consonantes en $-i a{ }^{68}$

Es posible que en el caso siguiente la situación sea la inversa; o sea, quizá ahora la versión portuguesa sea la original, y la castellana la traducción. En todo caso, en una y en otra la palabra tiempo aparece 22 veces:

De tempo em tempo tudo vai andando; o tempo sem pôr tempo vai correndo;

${ }^{67}$ Cancioneiro de Corte e de magnates, núm 278; como el copista es portugués, han sido precisos algunos retoques (por ejemplo, tormentos en vez de tromientos en el v. 11). El soneto está en varios otros manuscritos de la Bibl. Nacional de Madrid: el núm 598, fol. 179 = Reyes Messía de la Cerda, Discursos festivos... (Corpus Christi de Sevilla, 1594), Vicente Lleó Canal (ed.), Sevilla, 1895, p. 219 (en esta versión falta el v. 7, y los vv. 3-4 dicen: "Triste del que ve el tiempo tan trocado, / que algún tiempo al tiempo no temía”); —el núm. 861, p. 135; —el núm. 3168 (Cancionero de Jhoan López), Rosalind J. Gabin (ed.), tomo 1, Madrid, 1980, pp. 201 y 202; y el núm. 17.556 (Poesías varias, J. M. Hill (ed.), Bloomington, 1923). Se copia también, con buen número de variantes, dos veces en el manuscrito 3.358 de la Biblioteca Riccardiana de Florencia (en la segunda vez se atribuye a Diego de Soria).

${ }^{68} \mathrm{Y}$ sin embargo Juromenha lo incluyó en su edición de Camões (1861). Y a pesar de que Carolina Michaëlis de Vasconcelos mostró claramente la superchería — "Notas aos Sonetos anónimos", 112 y 113; e "Investigações sobre sonetos e sonetistas portugueses e castelhanos", 544 y 545 -, todavía Ma. de Lourdes Saraiva la pone en su edición de Lírica completa, Lisboa, 1980, tomo 2, 438, entre los "Sonetos de autoria controversa" ( ; como si hubiera "controversia" posible!). 
sem tempo não se vão os tempos vendo;

por tempo o tempo vai profetizando.

Do tempo, o tempo só pode ir falando;

a tempo se pode ir o tempo erguendo;

co tempo se vão tempos entendendo,

que o tempo vários tempos vai mostrando.

Nunca o tempo perdido é mais cobrado, que, se o tempo nos tira o que é presente, mal pode dar o tempo o que é passado.

O tempo gaste bem todo o prudente; que se o tempo que passa é bem gastado, tudo o tempo passado tem presente. ${ }^{69}$

La versión castellana es como sigue:

De tiempo en tiempo todo va pasando, que el tiempo más al tiempo va corriendo; consejo al tiempo el tiempo va pidiendo, que el tiempo a tiempos va profetizando.

De los tiempos el tiempo acierta hablando, que a tiempos se va el tiempo conociendo; con tiempo se van tiempos descubriendo, que el tiempo varios tiempos va mostrando.

Nunca el perdido tiempo fue cobrado porque el tiempo que vuela no se siente, y aun el tiempo no ve lo que ha pasado.

${ }^{69}$ Baltaçar Estaço, Sonetos, canções, églogas, fol. 20r; soneto reproducido por C. Michaëlis de Vasconcelos, "Notas aos Sonetos anónimos", 113. Está también, con variantes, en el manuscrito 17.719 de la Bibl. Nacional de Madrid, fol. 31r, intitulado "Soneto de un particular"; es el manuscrito, fechado en 1623, descrito por Juan Manuel Rozas, Cancionero de Mendes Brito, Madrid, 1965. 
Use del tiempo bien el que es prudente, que si el tiempo que pasa es bien gastado, todo el pasado tiempo está presente. ${ }^{70}$

\section{Finalmente, el ingenioso Rector de Vallfogona logró meter 26 veces la palabra temps en el siguiente soneto:}

Temps que sens temps passares com a temps, si del bon temps memoria, Temps, me deixas: com not llastiman, Temps, ab temps mas queixas antes que temps me vinga a faltar, Temps?

De temps en temps mudanças fa lo Temps; tu, Temps, immoble ab lo mal temps me deixas. Quant millor, Temps; se acabarán mas queixas, si per donarlas, Temps, me donas temps!

Ay temps! De temps demano sola una hora para lograr, o Temps, una hermosura que temps ha, Temps, mon cor esclau adora.

A ton nom, Temps, faré una estatua pura de aquest metall que el temps avaro dora, y agrairte he tot temps, Temps, ma ventura. ${ }^{71}$

\footnotetext{
${ }^{70}$ Soneto "Al tiempo", manuscrito 2883 de la Bibl. Nacional de Madrid, fol. 239. Obsérvese que en la versión portuguesa se repite la rima presente en los vv. 10 y 14, mientras que en la castellana no hay defecto; además, en el Cancionero de Mendes Brito, el verso inicial dice: “...todo vai passando", que parecería traducción de la versión castellana.

${ }^{71}$ Lo Parnàs Català, manuscrito D. 47 de la Boston Public Library, p. 11, cuyas erratas corrijo con base en la edición de Poesias de Vicens Garcia, Barcelona, 1820, p. 15 (epígrafe: "Al Temps, en cumpliment de la demana que se feu al autor precisantlo a anomenar 26 vegadas Temps"); vi también La armonia del Parnàs de Vicent García, Rector de Vallfogona, Barcelona, 1700, p. 15 (epígrafe: "Demanaren al autor fes un Soneto al Temps, en que hi hagués 26 vegadas Temps"). No modernizo la ortografía, ni lo intento siquiera, porque lo haría muy mal.
} 
Pero hay en estos barrocos tiempos dos sonetos, por lo menos, que en vez de repetir tiempo, tiempo, lo que repiten es cuenta, cuenta. He aquí el primero:

Vinde cá, pensamento, vinde à conta; dai conta onde fostes e viestes: que conta me dareis do que trouxestes? Somai a conta, bem vereis quê monta.

Dai conta, alma, de vós, e estai mui pronta a dar conta de todo o que fizestes; contai quem bem vos quis, quem vós quisestes, que, sendo bem, também se vos desconta.

Dai conta da despreza $[s i c]$ e recebido somai, e vede bem se é conta certa. Desde o tempo contai que haveis nacido;

a monta aclarai bem sem ter referta, que como não for conta de perdido, da Glória achareis sempre a porta aberta. ${ }^{72}$

Y he aquí el segundo:

Entré, amigo lector, conmigo en cuenta queriendo darte cuenta de esta obra, $\mathrm{y}$, por mi cuenta, hallé que aquello sobra que se pone de galas en La cuenta.

Y así, no es mi intención ponerme en cuenta con los que el tiempo cuenta, y de quien cobra nombre La cuenta, en que su ingenio obra primores, de que agora no hago cuenta.

${ }^{72}$ Cancioneiro de Corte e de magnates, núm 262. Según parece, otro tanto sucede en el soneto "De tudo quanto fiz quis fazer conta...", mencionado por C. Michaëlis de Vasconcelos en "Investigações sobre sonetos e sonetistas portugueses e castelhanos", 545 . 
Lo que a mi cuenta toca es darte llanos

los ásperos caminos de La cuenta, que en esto se descuenta mi cuidado.

Ten cuenta, pues, y toma entre las manos

este libro, y si de él hicieres cuenta, quedarás en La cuenta aprovechado. ${ }^{73}$

La siguiente octava es una especie de derivación o apéndice de los sonetos del tiempo y la cuenta en su vertiente devota:

Larga cuenta que dar de tiempo largo; término breve, tránsito forzoso; terrible tribunal, juïcio amargo, aun a los mismos santos espantoso; muchas las culpas, débil el descargo; recto el Jüez, y entonces riguroso; pleito en que va a gozar de Dios eterno o penar para siempre en el infierno.

Se puede leer en buen número de manuscritos, así españoles como portugueses. En el Cancioneiro de Corte e de magnates tiene este epígrafe: "Oitavas que fez Dom Ladron de Guevara estando para espirar, e acabando, acabou a vida”. El epígrafe de un manuscrito de la Hispanic Society of America no es muy distinto: "No ano de 16 [o sea 1616] compôs um poeta em

${ }^{73}$ Pedro Paz, soneto que sirve de prólogo a un manual de contabilidad que se imprimió en México en 1623. En su Biblioteca hispano-americana septentrional (comienzos del siglo XIX), Beristáin y Souza dice que el autor era "contador de diezmos" de la catedral de México. Vicente de P. Andrade, Ensayo bibliográfico del siglo XVII, México, 1899, 762 y 763, conoce dos ejemplares del libro, los dos sin portada y sin más preliminares que la aprobación, donde se habla de "arte de aritmética". Finalmente, Antonio Palau y Dulcet, Manual del librero hispanoamericano, dice que es "libro raro", y menciona "un ejemplar falto de preliminares" que en 1921 se vendió en 2 libras esterlinas. El texto del soneto hace pensar que el autor quería que su libro se llamara La cuenta (aunque el título sería más largo que eso). 
Madrid a oitava seguinte, e acabando de compor o derradeiro verso morreu súbito, tendo-se confessado o mesmo dia". ${ }^{74} \mathrm{La}$ octava mereció, además, los honores de la imprenta. Hay un pliego suelto cuya portada dice: Segunda parte del Desengaño del hombre, sobre la octava que dize "Larga cuenta que dar de tiempo largo", impresa en Salamanca en 1613; la octava va seguida de una glosa que consiste en ocho octavas, y comienza "Si duermes en tus vicios, alma mía...". 75

Los sonetos del tiempo y la cuenta tuvieron repercusión en Francia. He aquí una buena traducción-adaptación de "Pídeme de sí mismo el tiempo cuenta...":

\section{Le tems m'a demandé de ma vie le compte,} et moi j'ai répondu: "Le compte veut du tems,

${ }^{74}$ Cancioneiro de Corte..., núm. 244. En su nota, Askins menciona tres manuscritos de bibliotecas portuguesas y dos de la Hispanic Society. En uno de los manuscritos portugueses, el autor se llama Montalto, y en uno madrileño (Bibl. Nacional, ms. 17.557) el epígrafe dice: "Otava al Juicio, del marqués de Montesclaros". El nombre del verdadero autor importa menos que el hecho de que los lectores de esos católicos y barrocos tiempos veían con admiración y envidia el morir así, "en caliente", y subir al cielo por la vía rápida. Un caso semejante ocurrió en 1682 en México: cierto Carlos de Santa Rosa, aunque simple seglar, era muy devoto; murió en la noche del 11 de enero de 1680 sentado ante su mesa, al acabar de escribir unas coplas "A la muerte", cuyo último verso era "o morir o padecer"; durante el día fueron a verlo todos los vecinos de la ciudad, comenzando con el arzobispo-virrey fray Payo, y los señores de la Real Audiencia. Hubo que enterrarlo sigilosamente, a las 12 de la noche, "para evitar el concurso de la gente". Y parece que sor Juana Inés de la Cruz comentó el suceso en unos versos (que se han perdido). Véase sobre esto Antonio Alatorre, Sor Juana a través de los siglos, México, 2007, tomo 1, 315. Unos años después, cierto "eclesiástico de espíritu elevado" tuvo una visión del momento en que moría el padre Antonio Núñez, "rodeado de ángeles, y se le dio a entender que de la cama había volado su alma a la gloria": Antonio Alatorre, "La Carta de sor Juana al P. Núñez", 603, nota 27.

${ }^{75}$ En uno de los manuscritos de la Hispanic Society la octava tiene una glosa distinta, también en octavas reales: "—¿Qué sientes alma mía? —Que me voy...". Este pliego suelto se reimprimió al final del Confessionario general de Francisco de Soto, Cuenca, 1622. En él se incluye otra octava sumamente popular: "- $i$ Yo para qué nací? - Para salvarme...” cuyos versos finales (“¿Qué hago? ¿En qué me ocupo tiempo tanto? / Loco debo de ser, pues no soy santo") sirven como de estrambote a "Larga cuenta que dar..." en el manuscrito 3895 de la Biblioteca Nacional de Madrid. 
car celui qui sans compte a perdu tant de tems, comment, s'il n'a du tems, pourra-t-il rendre compte?"

Le tems m'a refusé de différer le compte, soutenant que mon compte a refusé le tems, et que, $n$ 'ayant fait compte en ayant eu le tems, en vain j'ai demandé du tems pour rendre compte.

O Dieu! Quel compte peut dénombrer tant de tems, et quel tems peut suffire à faire un si grand compte, lorsque vivant sans compte on abuse du tems?

Hélas! Pressé du tems et oppressé du compte, je rends l'âme et ne puis rendre compte du tems, puisque le tems perdu n'entre point dans le compte.

Se habrá observado que, a semejanza de lo que se hace en el modelo, hay repetición de tems/compte o compte/tems en los catorce versos. Pero también hubo una imitación francesa de estructura menos complicada, a semejanza del soneto portugués "Dos anos mal gastados pede a conta..." (supra, p. 68), que es un simple soneto continuo:

Du tems mal employé je trouve le mécompte, et je suis convaincu que c'est à contre-tems que l'on veut réparer une perte du tems sous la fuite duquel l'imprudent se mécompte.

Pourquoi compter sur lui si l'on n'en tient pas compte? Et pourquoi s'amuser au passage du tems, si lorsqu'il a coulé l'on veut, à contre-tems, répondre le passé pour produire son compte?

Vous, ô Père Éternel, qui gouvernez le tems, comptez si bien pour moi que je ne me mécompte. La mort, pour nos tromper, arrive à contre-tems 
et le compte pour lors n'est plus qu'un pur mécompte. Ainsi, pour profiter de la grâce et du tems, au sacre Tribunal je m'en vais rendre compte. ${ }^{76}$

\section{VI}

Todo lo muda el tiempo, Filis mía; todo cede al rigor de sus guadañas; ya transforma los valles en montañas, ya pone campo donde mar había;

él muda en noche opaca el claro día, en fábulas pueriles las hazañas, alcázares soberbios en cabañas, y el juvenil ardor en vejez fría.

Doma el tiempo al caballo desbocado, detiene el mar y viento enfurecido, postra al león y rinde al bravo toro.

Sola una cosa al tiempo denodado no cederá, ni cede, ni ha cedido, y es el constante amor con que te adoro.

No, claro que no es un soneto más de la era barroca, aunque trata de parecerse a ellos. El autor es José Caldaso (1741-1782), y "Filis" es María Ignacia Ibáñez, el amor de su vida. Es muy impresionante el caso de este poeta, que compuso intrascenden-

76 "Sonnet du tems et du compte" y "Sonnet du contre-tems et du mécompte", publicados por Joseph G. Fucilla en la revista Hispanófila, núm. 16 (septiembre de 1962), 109. Proceden del Nouveau choix de pièces tirées des anciens "Mercures" et d'autres journeaux, [París], 1764, 129 y 130. En este Nouveau choix, como dice Fucilla, se reimprimen libritos más antiguos, uno de ellos Le Glaneur littéraire, donde aparecieron por vez primera los sonetos. No dice Fucilla de cuándo es ese Glaneur littéraire, pero es de suponer que de comienzos del siglo XVII, cuando estaban de moda las traducciones de poesías españolas. $C f r$. Antonio Alatorre, "La popularidad de una letrilla de Góngora", 25-27. 
tes "anacreónticas" de gusto neoclásico (como las de Meléndez Valdés), pero que, al mismo tiempo, tuvo oídos, como ninguno de sus contemporáneos, no solo para el pasado (la poesía de los Siglos de Oro), sino también, por así decir, para el futuro: sus Noches lúgubres son un preludio del romanticismo, no solo español, sino europeo.

No he encontrado ecos parecidos en la poesía del siglo XIX, aunque no me extrañaría que alguien, mejor informado que yo, los encontrara en algún poeta menor, nacido en España o en cualquiera de las repúblicas hispanoamericanas. Pero en el siglo xx hubo un resurgimiento de los viejos artificios gracias a un grupo pequeño de amantes de la Musa juguetona. El primero, que yo sepa, es el mexicano Renato Leduc, autor de composiciones muy divertidas, entre ellas un soneto que tiene este arcaizante epígrafe: "Aquí se habla del tiempo perdido que, como dice el dicho, los santos lo lloran":

Sabia virtud de conocer el tiempo; a tiempo amar y desatarse a tiempo; como dice el refrán: "dar tiempo al tiempo"..., que de amor y dolor alivia el tiempo.

Aquel amor a quien amé a destiempo martirizóme tanto, y tanto tiempo, que no sentí jamás correr el tiempo tan acremente como en ese tiempo.

Amar queriendo como en otro tiempo - ignoraba yo aún que el tiempo es orocuánto tiempo perdí - ay- cuánto tiempo.

Y hoy que de amores ya no tengo tiempo, amor de aquellos tiempos, cómo añoro la dicha inicua de perder el tiempo. ${ }^{77}$

\footnotetext{
${ }^{77}$ Renato Leduc, Poesía y prosa, 88. Pero el soneto es muy anterior. No sé cuánto crédito merece lo que cuenta José Ramón Garmabella, Por siempre Leduc, 176: que hacia 1930, durante las aburridas clases de Julio Torri, sus alumnos se dedicaban a
} 
Una admiradora de Renato Leduc le envió el siguiente soneto:

Parafraseando tu soneto al tiempo, a escribirte me atrevo sobre el tiempo, Renato, pues tú añoras de aquel tiempo "la dicha inicua de perder el tiempo".

Misterio de ese enigma que es el tiempo, ni un ápice añadir se puede al tiempo, $y$, en su serena eternidad sin tiempo, nos destruye implacable todo tiempo.

¿Cuál es, si a cuentas vamos, nuestro tiempo, que nos resulta un bien desconocido?

Si es tiempo de esperar..., iqué largo tiempo!

Si es tiempo para amar..., iqué corto tiempo!

Sólo al morir habrémoslo vencido, y haremos de él ¡por fin! tiempo sin tiempo. ${ }^{78}$

\section{La huella del soneto de Leduc es visible en este otro:}

¿Qué triste es evocar todo aquel tiempo cuando ser era un simple pasatiempo, cuando yo derrochaba tanto el tiempo y negábame al oro que es el tiempo!

¡Qué rauda fue mi vida en otro tiempo...! ¿Qué necio fui al gastar mi poco tiempo en locuras banales, tan del tiempo, y al jugar a lo eterno en ese tiempo...!

retarse y a apostar con pies forzados; que alguien le propuso esto a Leduc: "hay que darle tiempo al tiempo", y que Leduc, incapaz de hallarle consonante a tiempo, hizo su soneto. (Lo que a mí me consta es que las clases de "Español superior" de Torri eran aburridas; asistí tres o cuatro veces a ellas en 1946, y lo que aprendí es que el superlativo de humilde no es humildísimo, sino humílimo, y que no se dice "a pie juntillas", sino "a pies juntillas").

${ }^{78}$ Alicia Delaval, Atrio del soneto, 95 y 96. 
Hoy que a mi edad sé del valor del tiempo, del dolor que me causa un contratiempo, de los celos de amores a destiempo,

mi latir se acompasa con el tiempo del reloj que, al flechar y dar su tiempo, señala al mío y grita: “¡Ya no hay tiempo...!”79

Siendo un hecho de conocimiento general que Time is money, no creo que Eduardo Lizalde haya dependido de ideas expresadas en sonetos anteriores - "y pierdo siempre el tiempo y pierdo el oro", "ignoraba yo aún que el tiempo es oro"- para escribir el siguiente:

Al tacto cuento el oro y cuento el tiempo, y pierdo siempre el tiempo y pierdo el oro, pues pierdo el oro por ganar el tiempo, y el tiempo pierdo por ganar el oro.

Compro, para vivir, oro con tiempo, y después pago el tiempo con ese oro. Aquel perdido tiempo era de oro y aquel oro tan pobre, puro tiempo.

Son lo mismo, sabemos, tiempo y oro y en desigual medida es muerte el tiempo y muerte como el aire ausente, el oro.

Oro se vuelve el polvo con el tiempo, enamorado polvo, polvo de oro, que es menudo caer, es oro, es tiempo. ${ }^{80}$

\footnotetext{
${ }^{79}$ Sebastián Martínez y Castro, "El valor del tiempo", en su libro Flechas, dardos y saetas, 31 .

${ }^{80}$ Eduardo Lizalde, Tabernarios y eróticos; reproducido en Un siglo de sonetos en español, Jesús Munárriz (ed.), 304. - El “enamorado polvo” del penúltimo verso es reminiscencia indudable de Quevedo, final del soneto "Cerrar podrá mis ojos la postrera...".
} 
En agosto de 1986, la infatigable Ulalume González de León publicó en la revista Vuelta, un díptico de sonetos que, según creo, son los únicos modernos que obedecen las leyes del viejo "Pídeme de sí mismo el tiempo cuenta...". (La autora, por cierto, pone el viejo soneto a guisa de epígrafe y, siguiendo el error de Méndez Plancarte y de Octavio Paz, se lo atribuye a fray Miguel de Guevara). El primero se llama "La Muerte":

El cuento de mis rostros cuenta el Tiempo — itodos, a un tiempo, vi en su espejo! —, y cuenta a cuenta: ese collar de muerto tiempo desgrana: ¿es tiempo de cerrar mi cuenta?...

¡En un tris daré cuenta de mi tiempo, del que hace tiempo perdí yo la cuenta: sin darme cuenta de que vuela el tiempo, pensé al Tiempo sin fin: días sin cuenta!

¿Borrón sin cuenta nueva quiere el Tiempo?... De que es tiempo de dar la vida a cuenta y mi dolor no cuenta para el tiempo,

¡ay, qué fuera de tiempo caigo en cuenta! "Peor es darse cuenta antes de tiempo", me dice el Tiempo y, ay, cobra la cuenta.

El segundo se llama "El Amor":

No me pidas, mi amor, cuenta del tiempo que estuve ausente, un tiempo que no cuenta junto al tiempo de amarnos. ¿Te das cuenta?: quien cuenta cuentos desperdicia el tiempo

de sin cuenta besar. ¡Fuera del tiempo volemos!... Si tu amante el tiempo cuenta de tu placer, al tiempo que a tu cuenta su cuenta ajusta, ¡mueran juntos tiempo, 
cuenta y silencio al alcanzar el tiempo

del fortissimo! A tiempo toma en cuenta:

aunque más de la cuenta es breve el tiempo

y antes de tiempo del amor da cuenta

tiempo en el tiempo abre el amor sin cuenta.

Ama entonces sin cuenta, ¡inventa tiempo!

Estimulado quizá por el ejemplo de Ulalume González de León, Severo Sarduy elaboró también un par de sonetos al tiempo:

I

Sin más demora le pedí la cuenta con el pretexto de que se iba el tiempo y no alcanzaba lo único que cuenta, lo que por un instante anula el tiempo.

A subterfugios acudió sin cuenta, para que ese anodino pasatiempo alcanzara su fin, a fin de cuenta. Pero todo era torpe, o a destiempo.

No sé qué sucedió. No me di cuenta de que ya había pasado tanto tiempo en aquel juego de siniestra cuenta

en que todo fue hastío y contratiempo, queriendo enderezar a riesgo y cuenta hasta la curva del espacio-tiempo.

II

La vida se acabó, no me dí cuenta de la velocidad que lleva el tiempo en su opaco fluir, ni de que cuenta cada instante perdido; tiempo al tiempo.

Se fueron, antes de sacar la cuenta, los años en los días, como el tiempo 
de arena, que parece que no cuenta

cada grano, un átomo de tiempo

que nada recüerda [sic]. Date cuenta

de cómo entre las manos se va el tiempo,

sacando en un soneto austera cuenta.

No me reproches que no tienes tiempo,

si en el total faltó lo que más cuenta:

la oscura enemistad del ser y el tiempo. ${ }^{81}$

Dice Sarduy que se ha inspirado en el viejo soneto "del poeta Miguel de Guevara" (información procedente quizá de Octavio Paz: Cfr. supra, nota 59). Pero en el viejo soneto, "Pídeme de sí mismo...", hay tiempo/cuenta o cuenta/tiempo en los catorce versos, que es la vía difícil elegida por Ulalume. Sarduy eligió la vía fácil.

\section{REFERENCIAS}

Aguilar y Tejera, Agustín, Las poesías más extravagantes de la lengua castellana, Madrid, Sanz Calleja, s. f.

Alatorre, Antonio, "La Carta de sor Juana al P. Núñez", Nueva Revista de Filología Hispánica, 35:2, 1987, 591-673.

Alatorre, Antonio, "La popularidad de una letrilla de Góngora", Anuario de Letras, 29, 1991, 17-40.

Antonio, Alatorre, Fiori di sonetti / Flores de sonetos, Antonio Alatorre (ed.), México, El Colegio de México, 2ª ed., 2009.

${ }^{81}$ Severo Sarduy, "Poesía bajo programa”, en La Gaceta del Fondo de Cultura Económica, marzo de 1998. Hay un nota (¿de Andrés Sánchez Robayna?) que dice: "Conferencia dictada en la Universidad Internacional Menéndez Pelayo en Santa Cruz de Tenerife el 9 de abril de 1991". Más que conferencia, es una "auto-antología". -En el segundo soneto, el [sic] del v. 9 tiene por objeto subrayar la extraña ignorancia prosódica de Sarduy: se puede usar diéresis en püeril (latín pu-e-ri-lis), pero no en recuerda (latín re-cor-dat). El "entre las manos" del v. 10 es reminiscencia indudable de Quevedo, “¡Cómo de entre mis manos te resbalas!...” (supra, p. 56). 
Argensola, vid. Leonardo de Argensola.

Arguijo, Juan de, Obra poética, S. B. Vranich (ed.), Madrid, Castalia, 1971.

Aquilano, Serafino, Le rime, Mario Menghini (ed.), Bologna, Romagnoli-Dall'Acqua, 1894.

Bonneville, H., Guirnalda odorifera (thèse complémentaire), Grenoble, 1969.

Boscán, Juan, Obras poéticas, Martín de Riquer et al. (ed.), Barcelona, 1957.

Cancionero antequerano, José Lara Garrido (ed.), Málaga, Diputación Provincial de Málaga, 1988.

Cancionero de Corte e de magnates, Askins (ed.), Berkeley / Los Ángeles, 1968.

Cancioneiro de Cristóvão Borges, A. L.-F. Askins (ed.), Braga, Barbosa \& Xavier, 1979.

Cancioneiro de Évora, A. L.-F. Askins (ed.), Berkeley/Los Angeles, University of California Press, 1965.

Cancioneiro de Fernandes Tomás, Carolina Michaëlis de Vasconcelos (ed.), Coimbra, Universidade de Coimbra, 1922.

Cancionero de Mendes Brito, Juan Manuel Rozas (ed.), Madrid, Consejo Superior de Investigaciones Científicas, 1965.

Cancionero de poesías varias (manuscrito 617 de la Biblioteca Real), J. J. Labrador et al. (ed.), Madrid, El Crotalón, 1986.

Cancionero y romancero sagrados de Justo de Sancha, Biblioteca de Autores Españoles, tomo 35.

Carbonero, León María, Esfuerzos del ingenio literario, Madrid, Succ. de Rivadeneira, 1980.

CARreira, Antonio "Algo más sobre textos y atribuciones en la lírica áurea", Voz y Letra, 2: 2, 1991.

Carrillo y Sotomayor, Luis, "Al ejemplo de las cosas que fueron y acabaron", Poesie, Fiorenza Randelli-Romano (ed.), Messina Firenze, Universitá degli Studi, Facultá di Magisterio, Istituto Ispanico, 1971.

Cartapacio poético del Colegio de Cuenca, J. Forradellas Figueras (ed.), Salamanca, 1984.

Catálogo de textos marginados novohispanos: Inquisición, siglos XVIII y XIX, México, El Colegio de México, 1992. 
Delaval, Alicia, Atrio del soneto, México, 1980.

De Vegas, Damián, Libro de poesía christiana, moral y divina, Toledo, Pedro Rodríguez, 1590.

De VIRUÉs, Cristóbal, Obras trágicas y líricas, Madrid, Esteban Bogia, 1609.

Die Strambotti des Serafino dall'Aquila, Barbara Bauer-Formiconi (ed.), München, Wilhelm Fink, 1967.

Estaço, Baltasar, Sonetos, canções, églogas, Coimbra, 1604.

Fernandes Raya, Manoel, Esperança engañada, Coimbra, 1624.

Faría y Sousa, Manuel de, Fuente de Aganipe, Primera parte, Madrid, 1627.

FucIlla, Joseph G., Estudios sobre el petrarquismo en España, Madrid, Consejo Superior de Investigaciones Científicas, 1960.

Foulché-Delbosc, Raymond, "136 sonnets anonymes", Revue Hispanique, 6, 1899, 328-407.

Foulché-Delbosc, Raymond, "237 sonnets”, Revue Hispanique, 18, 1908, núm. 171.

Foulché-Delbosc, Raymond, "Rimas del Incógnito", Revue Hispanique, 37, 1916, 251-456.

Garmabella, José Ramón, Por siempre Leduc, México, 1985.

Íñiguez de Medrano, Julián, La silva curiosa, Paris, $2^{\mathrm{a}}$ ed., 1608.

Jörder, Otto, Die Formen des Sonnets bei Lope de Vega, Halle/Saale, Max Niemayer Verlag, 1936.

Leduc, Renato, Poesía y prosa, México, Diana, 1979.

Leonardo de Argensola, Bartolomé, Rimas, J.M. Blecua (ed.), Zaragoza, Consejo Superior de Investigaciones Científicas, 1951.

Leonardo de Argensola, Lupercio, Rimas, J.M. Blecua (ed.), Zaragoza, Consejo Superior de Investigaciones Científicas, 1950.

LizALde, Eduardo, Tabernarios y eróticos, México, Vuelta, 1989.

Lope DE VEGA, Félix, Rimas [1609], en Obras poéticas, J. M. Blecua (ed.), Madrid, Planeta, 1985.

LoPe DE Vega, Félix [atribuida], "El rey por trueque", en Obras, Madrid, Real Academia Española (nueva edición), t. 2., 1916.

Lope DE VEGA, Félix, La serrana de Tormes, en Obras completas, Madrid, Turner, col. Biblioteca Castro, vol. 4, 1993.

Lope de Vega, Félix, La viuda valenciana, Teresa Ferrer (ed.), Madrid, Castalia, 2001. 
LóPEZ DE ÚBEDA, Juan, Vergel de flores divinas, Alcalá de Henares, 1582.

Martín de la Plaza, Luis, Poesías completas, J. M. Morata Pérez (ed.), Málaga, Diputación Provincial, 1995.

Martínez y Castro, Sebastián, Flechas, dardos y saetas, Irapuato, 1990.

Maurer, Christopher, Obra y vida de Francisco de Figueroa, Madrid, Istmo, 1988.

Méndez Plancarte, Alfonso, Poetas novohispanos, t. 1, México, Universidad Nacional Autónoma de México, 1942.

MichaËlis de Vasconcelos, "Notas aos Sonetos anónimos", Revue Hispanique, 7, 1900, 110-118.

MichaËLIS DE VASCONCElos, "Investigações sobre sonetos e sonetistas portugueses e castelhanos", Revue Hispanique, 22, 1910, 544 y 545 .

Michaëlis de Vasconcelos, Cancionero de Fernandes Tomás, Coimbra, 1922.

MunÁrriz, Jesús (ed.), Un siglo de sonetos en español, Madrid, Hiperión, 2000.

Montemayor, Jorge de, "Cancionero" [1562], en Poesía completa, J. B. Avalle-Arce (ed.), Madrid, Biblioteca Castro, 1996.

Navarro Durán, Rosa, "El soneto de Sasso 'Col tempo el villanel al giogo mena' y Lope de Vega", Anuario de Filología, 7, 1981, 391-409.

P. AndRADE, Vicente de, Ensayo bibliográfico del siglo XVII, México, Imprenta del Museo Nacional, 1899.

Paz, Octavio, Anthologie de la poésie mexicaine, Paris, unesco/Nagel, 1952 (Série ibéro-americaine 2).

PAz, Pedro, Biblioteca hispano-americana septentrional, México, 1623.

Plaza, Luis Martín de la, Poesías completas, J. M. Morata Pérez (ed.), Málaga, Diputación Provincial, 1995.

Quevedo, Francisco, Obras en prosa, Luis Astrana Marín (ed.), Madrid, Aguilar, $2^{\mathrm{a}}$ ed., 1941.

Rodríguez Marín, Francisco (ed.), Primera parte de las Flores de poetas ilustres de España... ordenada por Pedro Espinosa, Valladolid, 1605; edición de... Sevilla, 1898. 
Soto de Rojas, Pedro, Obras, Antonio Gallego Morell (ed.), Madrid, Consejo Superior de Investigaciones Científicas, 1950.

SuÁrez de FigueroA, Cristóbal, El pasajero, M. I. López Bascuñana (ed.), Barcelona, Propociones y Publicaciones Universitarias, 1988.

Tasso, Torquato, Poesie, Francesco Flora (ed.), Milano-Roma, Rizzoli, 1934.

VIRUÉs, Cristóbal de, Obras trágicas y líricas, Madrid, 1609.

Vitale, Mario, "Sul sonneto Al tempo di Torquato Tasso", Aspetti Letterari, 18, 1958, 36-40. 